Article

\title{
Developing Goals and Indicators for the Design of Sustainable and Integrated Transport Infrastructure and Urban Spaces
}

\author{
Liu Yang $1,2, * \mathbb{C}$, Koen H. van Dam ${ }^{3}\left(\mathbb{D}\right.$ and Lufeng Zhang ${ }^{2}$ \\ 1 School of Architecture, Southeast University, Nanjing 210096, Jiangsu, China \\ 2 Center of Architecture Research and Design, University of Chinese Academy of Sciences, \\ Beijing 100190, China; zhanglufeng@ucas.ac.cn \\ 3 Centre for Process Systems Engineering, Department of Chemical Engineering, Imperial College London, \\ London SW7 2AZ, UK; k.van-dam@imperial.ac.uk \\ * Correspondence: yangliu2020@seu.edu.cn
}

Received: 14 October 2020; Accepted: 16 November 2020; Published: 19 November 2020

check for updates

\begin{abstract}
This paper aims to provide a framework for policy-makers and transportation and urban design professionals to evaluate alternative urban plans and infrastructure design, allowing them to select a set of locally relevant indicators to help assess scenarios considering sustainable development and overall system performance improvement in line with specific project goals. Using methods of systematic review, content analysis, multi-criteria analysis, and expert consultation, a three-level goal system is proposed, leading to the generation of 64 Key Performance Indicators (KPIs), both qualitative and quantitative, and an indicator set of 227 items. To allow stakeholders to apply their own set of indicators, the approaches and tools of measuring these indicators as well as the ways of using this indicator set are presented to assist decision-makers in evaluating and choosing optimal plans and designs.
\end{abstract}

Keywords: transport system; urban spaces; sustainable design; evaluation; indicator system

\section{Introduction}

The set of United Nations (UN) Sustainable Development Goals (SDG), particularly SDG Goal 11 to "make cities inclusive, safe, resilient and sustainable", provide structure and objectives for a more sustainable future for all, anywhere on the planet [1]. To link these overarching goals to local decision-making processes, clear, project-oriented goals and operational objectives are needed. Guidelines or frameworks allow decision-makers to develop their own goals in specific socio-economic contexts and under certain project requirements. In transport and urban planning discourses, goals and evaluation are also paramount steps in the decision-making process. For example, in order to make a rational decision on an urban plan, it is necessary to accurately and systematically describe the urban system under study, to assess the advantages and disadvantages of the proposals, and to estimate system changes over time as a result of their implementation [2].

In the urban transport sector, transportation infrastructure has been constructed without serious consideration of the potential negative impact on cities' public spaces, its users, and the environment during the past decades [3]. For instance, railways divide the surrounding urban fabric into fractured, inaccessible, and unfriendly areas, which has a negative impact on individual daily commutes, quality of life, and the natural environment. Studies on sustainable and integrated design of transport infrastructure and urban spaces, which prioritise the needs of people, ecology, and better places over mobility enhancement, have attracted widespread interest [4,5]. Yang et al. [6] stated that transport, 
spaces, and humans interact with each other and form an integral system that is interplaying with its surrounding policy and the natural environment. Based on a state-of-the-art review, they highlighted the need for a systematic and thorough "evaluation of integrated transport-spaces-humans plans". The selection of relevant indicators to help with this evaluation is, in the end, the responsibility of the key problem owner, and it is essential that the selected indicators are selected through a structured and transparent process.

Of note is that the issue of transportation and urban spaces integration has been studied at different scales and by scholars from diverse disciplines (see Figure 1). At the macrospatial level, transport and urban planners commonly approach the urban spaces system through the prism of urban spatial structures and urban forms, where land-use planning is a powerful tool [7-9]. At the microspatial scale, urban designers and architects explore the integrated design of transport infrastructure lines, stations, and public spaces that directly impacts citizens and users [10-12]. While the evaluation of the integrated plans in the macro-level scope has been extensively explored [8,13], this research focuses on the assessment of the integrated designs at the micro level, i.e., the interface between transport and public spaces where denizens interact. Because the quality of high-level urban area planning will determine the design condition of low-level public spaces, and in return, microscale environments can give insights for the macroscale strategic planning, evaluation of the macroscale spaces (e.g., land uses) should be taken into account when identifying microscale indicators [12]. In this case, this paper considers urban spaces at both scales to maintain consistency of goals and evaluation criteria.
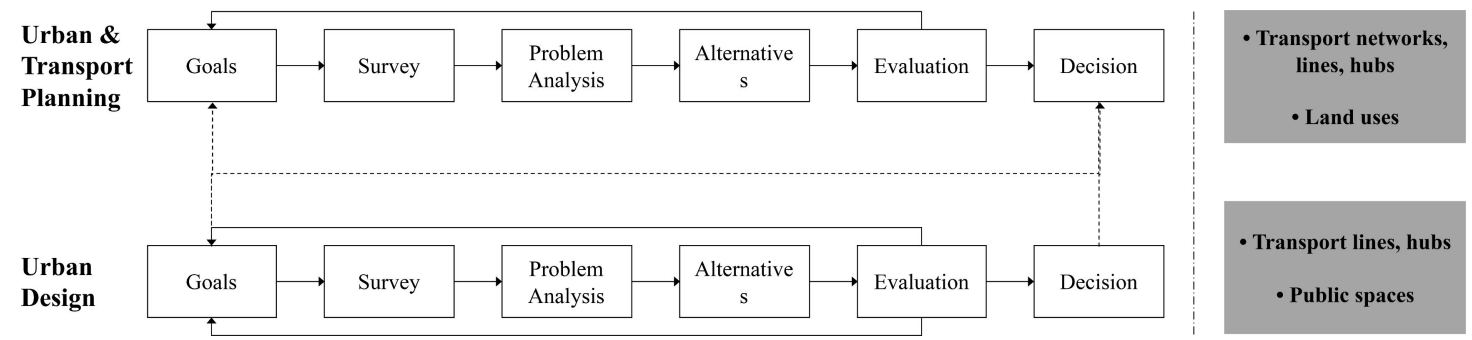

Figure 1. Different stages of transport and urban planning and urban design. The words in grey boxes explain the meanings of the transport system and the urban spaces system at macro and micro scales. Adapted partly based on [14], p. 19.

A transport system in the context of this paper refers to the land transport system in cities, including rail and road transport. The former could be categorised into intra-city rail transit (e.g., railways) and inner-city rail transit (e.g., tramways), while the latter includes roads and highways. In general, urban spaces can be classified into private, semi-public, and public spaces according to their ownerships. Following the definition given by Lévy [15], a public spaces system, in this study, denotes the urban areas that are socially owned and accessible for all, including streets, open spaces, and public amenities. Finally, the humans system in this research implies the behaviour of humans, including active travel (e.g., walking, cycling), recreational activity, social interactions, and behaviour regarding choice of travel mode.

Despite the growing awareness of building integrated transport-spaces-humans plans and the numerous investigations on transport and urban planning evaluation, more work is needed to provide interdisciplinary support for evaluating the performance of such integrated plans considering sustainability goals. Assessment of the baseline and the planned system performances in line with their sustainability benefits are of paramount significance to support rational decision-making as well as public consultations and building support for new plans. To this end, we first ask the following questions, motivated by the Jing-Zhang high-speed rail project in Beijing, which is currently in the stage of evaluating and implementing the masterplan. The government needs an appropriate framework to support decision-making. Discussions with several key stakeholders and local experts (see Acknowledgements) have shaped these questions: 
- Q-1: What kinds of goals and objectives should be set up for integrated transport-spaces design?

- Q-2: Which Key Performance Indicators (KPIs) should be used for evaluation?

- Q-3: What kind of indicator system is capable of supporting scientific and interdisciplinary evaluation?

To answer these questions, this paper aims to first provide a benchmark for generating goals in different projects and then to propose an indicator set for evaluating the performance and sustainability of integrated transport infrastructure and urban spaces design. Such a transparent goal system is beneficial in interdisciplinary (or even transdisciplinary) transportation research where professionals, decision-makers, and the public are involved in developing the goals and strategies collectively [16]. The indicators presented here are not specific for any particular case study, but this paper provides a framework of indicators that can be relevant for any individual project, though the specifics will have to be aligned based on local individual circumstances. The authors attempt to promote progress in addressing transportation and urban spaces system sustainability in research, practice, and education. Such decision frameworks are directly applicable to project managers, but the overview presented in this paper could also be applied by educators to provide students with example indicators to be considered in their coursework or student projects, or to evaluate real-world example scenarios from a systems perspective.

The paper is organized as follows. In Section 2, we first build on the literature, reviewing relevant literature in urban planning and design evaluation and indicators selection. Next, Section 3 refines the research questions this paper attempts to address, proposes an overall framework for indicator set development, and details the approaches used in a systematic literature review. Section 4 presents the results of a goal system, a set of KPIs and a preliminary longlist of indicators, and the final indicator set, subsequently. Section 5 discusses the ways of applying such an indicator set and the appropriate methods of evaluating the qualitative and quantitative indicators outlined in the collection. Finally, the paper is concluded in Section 6, reflecting on how these indicators can be used to support decision-making.

\section{Literature Review}

To build upon the literature, we reviewed five parts of previous research: (1) goals set up for integrated transport infrastructure projects, (2) evaluation in urban planning, (3) transport and urban spaces systems assessment, (4) criteria of indicators selection, and (5) methods used in generating an indicator set.

\subsection{Goals of Integration in Transportation Infrastructure Projects}

Saidi et al. [17] divided the goals of infrastructure system integration into four levels: (1) high-level integration within an individual subsystem, (2) detailed-level integration within a specific subsystem, (3) high-level integration between multiple subsystems, and (4) detailed-level integration between various subsystems. For transportation infrastructure, Heeres et al. [18] proposed an instrumental matrix of integration, categorising a set of solution spaces (i.e., "the conceptual space in which possible solutions might be found" [19]) of integration. From a functional and spatial perspective, they identified three degrees of integration, including:

- No integration: Infrastructure projects are planned separately without coordination with urban spaces planning.

- Sector-internal integration: A multi-modal transport network is embedded in the transportation infrastructure that connects different urban areas.

- External integration: The focus is extended from merely improving the connectivity of the transportation system to integrating with other related urban systems, especially the integrated design of public spaces, natural systems, human behaviour, and land use. At the same time, the integrated design of this type of project is not only at the strategic level but also at the implementation and operation level. 
These degrees can be used to accurately describe which (sub)systems need to be taken into account in the analysis.

\subsection{Evaluation in Planning and Urban Design}

In planning and urban design discourses, several evaluation paradigms have developed gradually to support the decision-making. Since the 1970s, scientific, systematic, and objective aspects have been emphasised in urban planning, the evaluation was aiming at "best plans" selection, and the cost-benefit analysis was widely used. In the following decades, social, environmental, and economic aspects of urban planning have gained increasing concern. Researchers and practitioners started using a series of tests to choose the solution that best meets the requirements outlined by project goals and evaluation criteria and using evaluation questions to judge the success of planning (for a review see [20]). Chadwick [2] demonstrated that evaluation and the formulation of goals and objectives are interdependent and interactive procedures in systematic planning. Assessment tasks include assessing project goals, baseline system performance, different plan scenarios, planned system performance, the impact of multiple policies, and the final decision.

In ex-ante and ongoing evaluations, "conformance-based" and "performance-based" views are adopted [20]. The former focuses on whether the implementation plan is consistent with the project's proposals and goals; the latter expands assessment scope to the overall benefits to the city (e.g., sustainability), following the recognition of planning as a continuous decision-making process under uncertainty $[8,21]$. In such, performance-based evaluation, considering the emergence of complex changes in cities, holds promise for sustainable planning. Similarly, in the urban design field, conventional urban design uses morphological and aesthetic quality as the evaluation criteria. In contrast, contemporary urban design adopts multi-dimensional impact assessments to appraise design quality [22]. Among numerous assessment approaches, Environmental Impact Assessment (EIA) [23,24] and sustainability assessment [25-27] are of growing interests. Sustainability assessment that includes not only physical environment evaluation but also socio-economic-environmental evaluation is also called the third generation of impact assessment [28].

\subsection{Assessment of Transportation and Urban Spaces Systems}

In the transport sector, Arcdis [29] investigated mobility through the three pillars of sustainability and used 23 indicators for their sustainable cities mobility index. Based on 16 indicator initiatives developed in Europe, North America, and Oceania, Jeon et al. [30] summarized the frameworks and indicators for a transport sustainability assessment, arguing that system effectiveness, efficiency, and environmental impacts are fundamental metrics. Taking into account both sustainability assessment and economic returns, [31,32] presented an overview and an evaluation approach of the transport system evaluation. In the urban spaces sector, Yu et al. [33] appraised urban spatial development through a sustainability evaluation system.

Apart from the research on evaluating transport and spaces systems separately, numerous studies examined the mechanism of Land Use and Transport Integration (LUTI) as well as the prediction of their reciprocal impacts $[7,9]$. Methods of surveys, empirical studies, and mathematical and computational models have been widely used. One of the most influential works is the "transport land use feedback loop" initially proposed by Wegner [13] and adapted by Bertolini [8], which summarizes the relationship between land use, activities, transport systems, and accessibility. In [8,34], the necessity of educating students and professionals in integrated transport-land-use thinking and integrated modelling skills was emphasized. After critically reviewing all LUTI models, Acheampong [35] pointed out that the environmental impact considerations are still very limited in existing LUTI models. To this end, Yigitcanlar and Dur [36] developed a holistic Sustainable Infrastructure Land-use Environment and Transport Model (SILENT) that captures the interaction between demography, transport, land use and urban form, and the environment, with a spatial resolution of $100 \times 100 \mathrm{~m}$. Another example is the Wellington Integrated Land Use-Transport-Environment Model (WILUTE) which takes into 
account metrics of transport-related energy consumption and pollutants, public health benefits, the adaptive capacity to sea-level rise, and first-round socio-economic outcomes [37].

\subsection{Indicator Types and Selection Criteria}

To assist the aforementioned measurements and planning decisions, indicators are extensively used. They can be defined as statistical data that evaluate certain aspects of a particular research phenomenon and are a method for measuring abstract concepts [38]. Indicators can be divided into qualitative and quantitative components. The former is used to assess objective attributes, while the latter uses numerical values to measure the characteristics of objects. Typically, these two indicator types are adopted complementarily in the construction of an indicator system, which experiences a transition from a single indicator to a multi-dimensional and multi-scalar system. More specifically, to evaluate urban system performance, Key Performance Indicators (KPIs) (or performance indicators) are a powerful tool and of significance in sustainable planning [39].

The decision of indicators should follow a series of criteria. Coombes et al. [40] argued indicators need to (1) be supported by data, (2) have spatial meanings, (3) be operable, (4) be transformable and interpretable, and (5) consider time continuity and dynamic. Garau and Pavan [41] stated that indicators should feature (1) objectivity, i.e., be clear, easy to understand, and accurate; (2) relevance, measurability, and repeatability; (3) validity, i.e., can be verified, with high data quality; (4) representativeness; (5) comparability, i.e., are comparable at different space and time conditions; and (6) availability, i.e., data are easy to obtain. Also, the time and human resources required to evaluate the indicators should be considered to make the use of the indicators feasible and manageable. Under this prism, indicators should be as few as possible, though critical factors cannot be omitted [42].

\subsection{Methods and Procedures of Indicator Set Generation}

There are two fundamental ways to establish an indicator system: Delphi and Multi-Criteria Analysis (MCA). The Delphi method is based on experts' knowledge, experience, intuition, reasoning, preferences, values, application following steps of an expert panel formation, asking questions, experts commenting, feedback collection, judgment, and synthesis [43]. MCA, which is capable of taking account of multiple different criteria when constructing an evaluation system, is more objective, systematic, and time- and human resource-efficient in comparison with Delphi. The goals-achievement matrix is a significant multi-criteria decision method [44,45]. In doing this, researchers first define a set of goals, and then break them down into objectives and sub-objectives constantly until they can be measured by quantitative or qualitative indicators, after which an indicator set is formed. In general, goals refer to the long-term, high-level targets pursued by urban development, which may not be achievable at this stage due to certain conditions. Objectives are short-term, low-level steps for goal attainment, which are specific, measurable, achievable, realistic, and time bound. To support the development of indicator sets for the transport sector, Sdoukopoulos et al. [46] summarised a general iterative method, while Castillo and Pitfield [47] presented an Evaluative and Logical Approach to Sustainable Transport Indicator Compilation (ELASTIC) framework consisting of six procedures. In [41], a seven-step method grounded in MCA for measuring the overall sustainability of cities was proposed.

After reviewing the previous work, we found that the majority of the works simply collects a set of indicators, while the connection between the goals for transport and urban spaces planning projects and the indicator sets requires clarification. Furthermore, though some indicator sets introduce themes or categories for structuring indicators, the choice of these themes is problematic due to a lack of systematic underpinning. The sustainability assessment falls either in the transport sector and public spaces sector separately, or in the transport-land use interaction, while the interface of transport infrastructure-public spaces and the human users in this context still falls short. 


\section{Methodology}

To address the research questions, the novelty of this paper lies in defining a system of benchmark goals and objectives, outlining a series of evidence-based themes and KPIs, and developing a systemic indicator set, which is classified and mapped corresponding to the goal system. The proposed indicator set can then help track progress in achieving the overall sustainability goals of an integrated transport-spaces design. In spite of attempting to capture all the sustainability pillars (i.e., social, economic, and environmental) of the transport-spaces system, this paper focuses on the environmental aspect, that is, on environmental impact assessment.

\subsection{A Three-Step Framework}

This research applies the MCA method to generate a set of indicators. By synthesising and narrowing down the several steps presented in $[41,46,47]$, we utilize a three-step framework to guide our research (see Figure 2) as follows:

(1) A goal system construction: identifying goals and objectives.

(2) Theme and KPI identification: first, conducting a systematic literature review; second, extracting themes by keyword and content analysis; and third, analysing and synthesising the findings, leading to KPI elicitation.

(3) Indicator set development: first, forming a longlist of indicators based on the systematic review; second, shortlisting indicators in light of certain criteria; third, subdividing the indicators when necessary and describing, explaining, and standardising each indicator; fourth, consulting 10 experts in transport and urban planning about a draft of the indicator set; and last, finalising the overall indicator set.

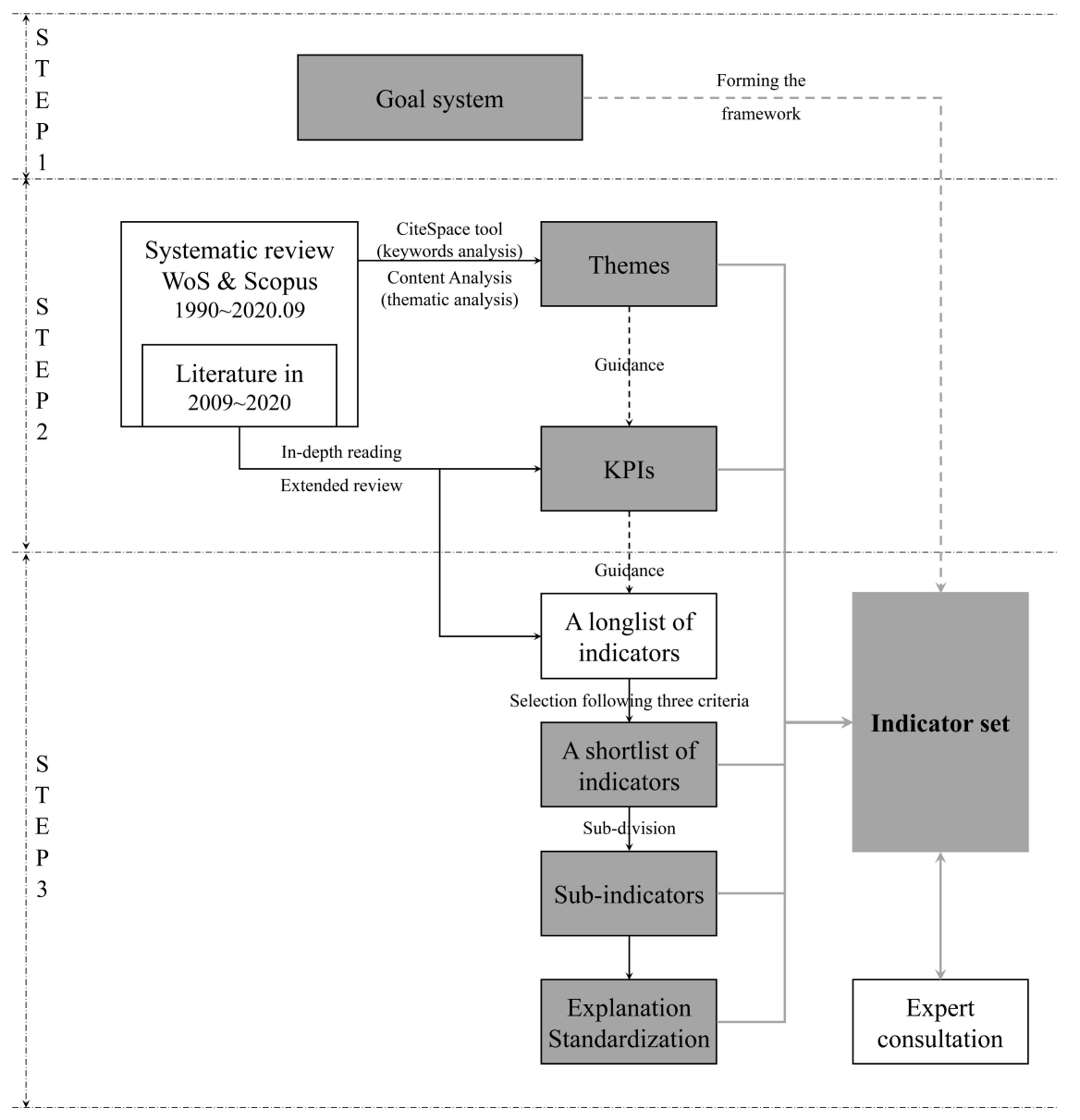

Figure 2. The three-step methodology used in this research. 


\subsection{A Systematic Literature Review}

The approach and process adopted in this literature review are inspired by [31,48]. Initially, to select accurate themes, KPIs, and a longlist of indicators for evaluating transportation infrastructure and public spaces systems, we conducted a database search on Web of Science (WoS, Core Collection) and Scopus for all years (until 30 September, 2020). They complement each other and archive the academic literature from a broad range of disciplines by connecting different databases, thus providing references from across the spectrum of expertise related to transport and planning (and other related disciplines) for the selected keywords [49]. The first set of search words used for exploring transport infrastructure assessment research was (Transport* Infrastructure AND Evaluation AND Indicator), and the second set used for investigating public spaces appraisal studies was (("Public Space" OR "Urban Space") AND Evaluation AND Indicator). In the first set, "transport" was used to retrieve words of transport and transportation, which are always interchangeable. In the second set, both "public space" and "urban space" were contained to engage alternative terms and different spatial scales of the transport-spaces plan. These terms were used to search the field of Topic in Web of Science and applied to the fields of Article title, Abstract, and Keywords when searching in Scopus. As a result, Web of Science returned 249 (transport evaluation) and 357 (spaces evaluation) sources of literature and Scopus returned 333 (transport evaluation) and 98 (spaces evaluation) results. After removing the duplicates, the result was 435 (transport evaluation) and 424 (spaces evaluation) records.

In order to extract themes from these publications, the CiteSpace technique and content analysis were applied. CiteSpace is a literature analytical tool to visualise trends and patterns in the literature, such as about the growth of specific fields over time and their geographic spread, and is particularly powerful for conducting computerised analysis of keywords [50]. This study used CiteSpace to investigate keywords appearing in the study of transportation infrastructure assessment and public (and urban) spaces assessment. Content analysis is a useful research method for the objective and systematic investigation of documents, especially for coding the texts in accordance with certain subjects and themes [51].

Furthermore, literature published in 2009-2020 (more than 90\% of the indexed literature found was from this period) was reviewed thoroughly to first determine KPIs. After an overview of their titles and abstracts, 57 relevant documents were selected for in-depth reading. In addition to these sources, we reviewed the references they cited and the references in which they were mentioned to reach literature not captured from the Web of Science and Scopus keyword searches but that is influential in the topics of sustainability assessment, liveability assessment, public space quality evaluation, and community severance. This extended review led to a total of 27 books and journal articles. After selecting the KPIs, we sorted and synthesised the indicators reported in these documents, leading to a longlist of indicators. The longlist was then screened based on three criteria, which resulted in a shortlist of indicators:

- Relevance to the theme: Indicators for assessing the quality of underground urban spaces and the impacts of surrounding areas (e.g., building facades) on public spaces are not considered in this research. Although the longlist involves all sustainable indicators, i.e., social, economic, and environmental factors, this article focuses on the natural environment aspect, so only indicators relevant to the environment are retained.

- Integration of similar indicators: To assure the independence between indicators and avoid duplication and overlap, related items are merged into a single indicator where possible.

- Necessary evaluation items inclusion: Elements in the analysed system are not independent, so the impact on other aspects needs to be taken into account. The evaluation of public spaces systems takes account of the factors of adjacent transportation structures. For example, when public space is surrounded by elevated railways, the shadowing effect of the latter should be considered. 


\section{Results}

This section describes the outcomes of the process described above, first presenting the goal system, then the longlist of KPIs, and finally the selected indicator system for integrated and sustainable transportation infrastructure and urban spaces design.

\subsection{Goal System for Evaluating Transport and Spaces Systems}

\subsubsection{Hierarchy of the Goal System}

In line with $[17,18]$, an integrated transportation infrastructure system should achieve both sector-internal integration and external integration with other sectors. Furthermore, according to complex systems theory, system integration aims to coordinate not only the interrelationships among internal elements of a subsystem but also the relation between the subsystems and with the external environment. In such, the human-made transport-spaces system needs to be coordinated with human and ecological systems. In this regard, we present a multi-level solution space to assess the integration degree of a status quo system or a designed system, as illustrated in Figure 3:

- Integration of the subsystems (the transport system and the spaces system) considering human behaviour;

- Integration between two subsystems (transport-spaces-humans system) themselves;

- Integration between the transport-spaces-humans system and the (external) natural environment system considering social and economic impacts.

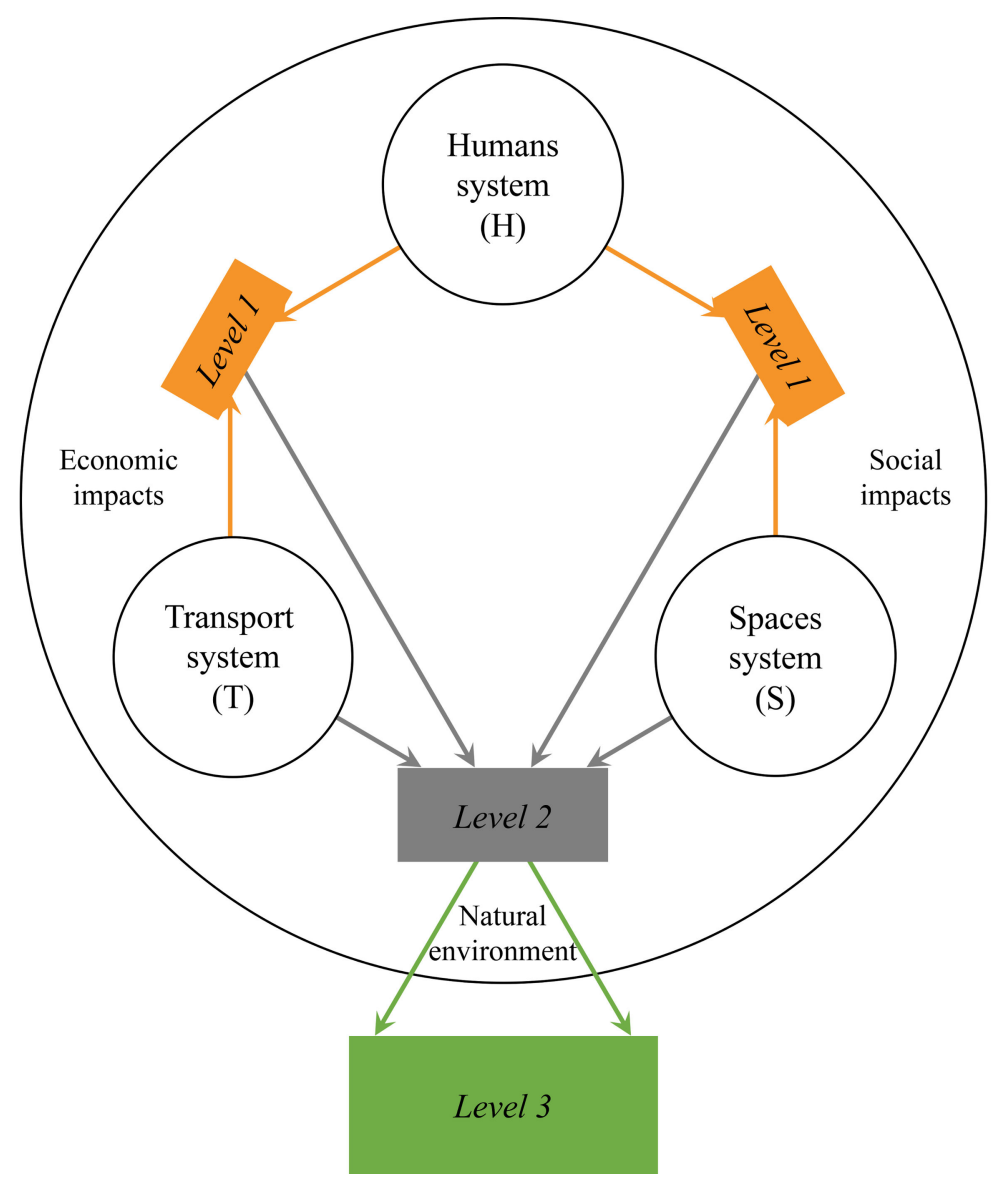

Figure 3. Illustration of a goal system. 


\subsubsection{Goals}

Following this multi-level solution space, the overall goals of transportation and urban area planning projects can be defined. From a long-term perspective, the integration of transport and spaces needs to meet basic human needs and external ecosystem needs, achieve a balance between liveability and mobility, follow the principles of sustainable development, and contribute to building eco-, healthy, and intelligent cities. Therefore, goals consist of three levels:

- Level 1: Interdependence between the elements of the transportation infrastructure system and the urban spaces system are coordinated to achieve a synergy. In parallel, basic human needs are fulfilled through short, medium, and long-term people-oriented infrastructure development.

- Level 2: Mutual reciprocity between transportation systems and urban spaces systems is generated at elemental, spatial, and regional scales. Needs for mobility and liveability are balanced while people's healthy behaviour is promoted [5,52].

- Level 3: Reciprocity between the transport-spaces system and the external environment is obtained. Material, energy, and information exchanges between transport-spaces systems and ecosystems (as well as social and economic systems) are optimised while satisfying both human and ecological needs in pursuit of overall sustainability.

\subsubsection{Objectives}

Based on these high-level goals, three groups of objectives are derived. Note that for realistic transportation infrastructure (re)development projects, the formulation of objectives should also recognise and balance the project constraints, which are external conditions and typical features of a site that restrain the planning and construction process. For instance, time constraints, budget, local policies, social issues and customs, cultural backgrounds, and available land are significant factors (a full list of project constraints can be found in [53]).

- Level 1: Synergy between internal elements of the transport system and the urban spaces systems are created to meet the human needs of mobility and liveability.

To satisfy mobility demands, it is necessary to (1) configure connected and accessible transportation networks and nodes for each transport mode, (2) build an efficient connection between different transport modes, and (3) make public transport and active travel the dominant transport modes. To satisfy liveability demands, the design of transportation and spaces systems should accomplish objectives of: (1) a sense of place, (2) mixed-use, (3) density, (4) design for the use of the vulnerable population, (5) high environmental quality, (6) green infrastructure provision, (7) safety, and (8) public health [54].

- Level 2: Mutual reciprocity between transport and spaces systems is developed, with mobility and liveability needs balanced and healthy behaviour stimulated.

In an attempt to achieve integration of transport infrastructures and affiliated urban spaces, the two systems should be designed holistically from visual, spatial, functional, and psychological perspectives. To balance the two human needs, the accessibility and connectivity of active transport networks should be increased in the transport system; the quality and continuity of public spaces ought to be enhanced in the spaces system.

- Level 3: Reciprocity between the transport-spaces system and the external environment is stimulated, leading to an improvement of overall sustainability in cities.

In this respect, sustainable planning and design strategies are needed. Sustainable transport infrastructure planning should avoid, reduce, and compensate for the negative impacts of infrastructure construction on individuals, communities, and ecosystems [55]. Sustainable urban spaces design 
should provide a healthy environment for residents by adjusting the factors of solar, wind, air quality, temperature, rain, sound, and noise [56]. Furthermore, the construction, maintenance, and abolishment of transportation and public spaces infrastructure should adopt the "circular economy" concept, that is, reducing the usage, improving the reuse, and enhancing the recycling of raw materials [57]. Other considerations include the promotion of economic efficiency, public health, social justice, cultural heritage protection, and social satisfaction.

\subsection{Descriptive Data Analysis}

\subsubsection{Temporal Dimension}

Research on "transport evaluation indicator" and "public (OR urban) spaces evaluation indicator" recorded on Web of Science and Scopus mostly appeared after the year of 2000, with only one and four publications before 2000 in transport and spaces domains, respectively. Figure 4 presents the results found in the new millennium.

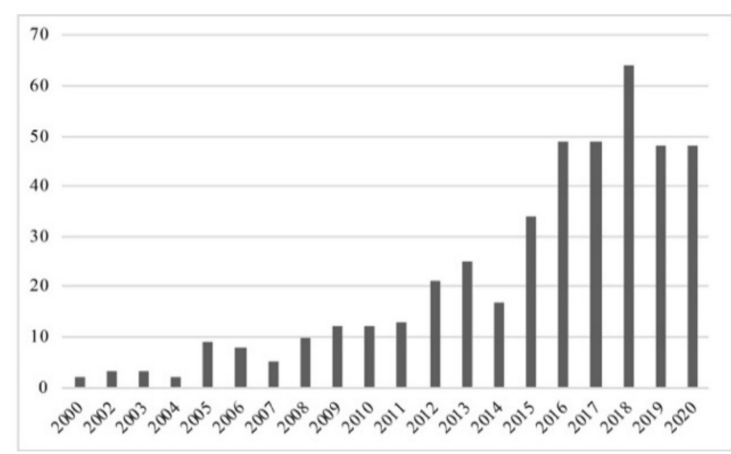

(a)

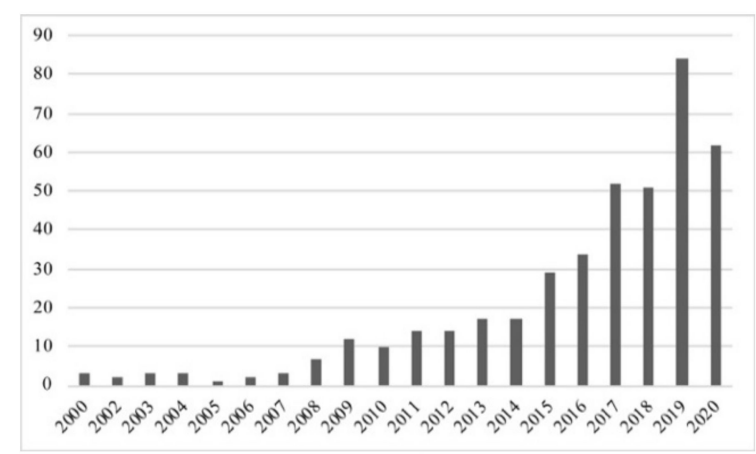

(b)

Figure 4. Search records from Web of Science and Scopus databases on the topics of (a) transport evaluation indicators and (b) public (OR urban) spaces evaluation indicators. Period: 2000-2020 (September).

As shown in Figure 4a, the number of papers relating to transport evaluation research was simply two in the year 2000 but peaked at 64 in the year 2018. More than $87 \%$ of publications were after 2010 and in the last five years more than 48 papers were published annually. From Figure $4 \mathrm{~b}$ it can be found that interest in the research topic of urban and spaces assessment has increased remarkably; in the year 2019 alone, 84 papers were recorded.

By comparing the number of publications on both topics in different time periods, Figure 5 indicates that evaluation indicator studies in the transport sector burgeoned earlier than those in the urban spaces sector, but that the latter have gained much more attention since 2016. More specifically, research in the topic of transportation evaluation saw a remarkable increase after 2005 and the research on urban/public spaces appraisal started to attract increasing attention three years later, as illustrated in Figure 4. Similarly, both threads of studies were documented mainly in the last five years, with $59.3 \%$ of transport assessment literature and $66.8 \%$ of urban spaces appraisal literature occurred in this period. 


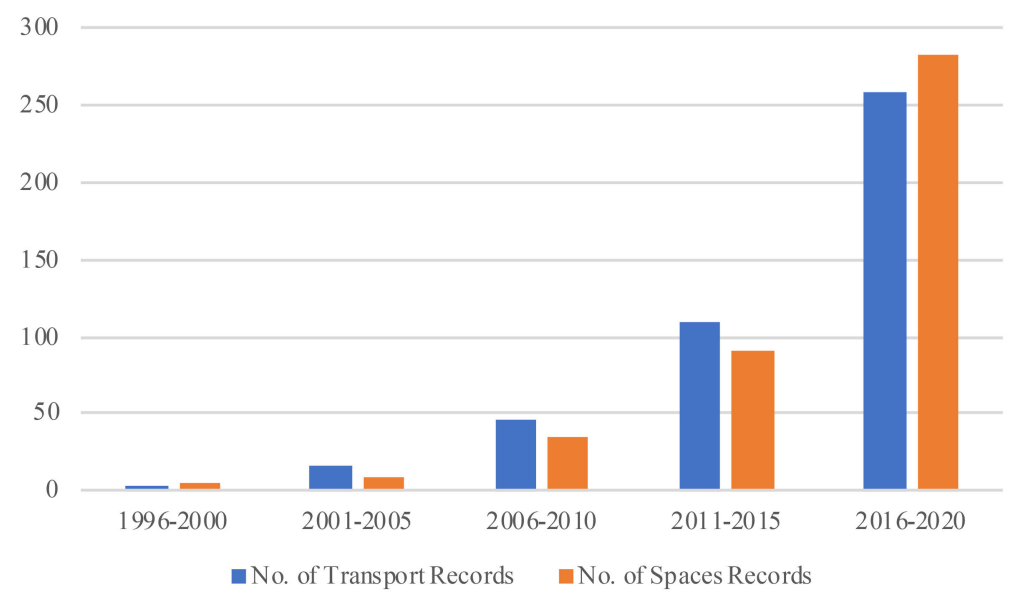

Figure 5. Search records from the Web of Science and Scopus databases on the topics of transport evaluation indicators and public (OR urban) spaces evaluation indicators in different time periods from 2000 to 2020 (September).

\subsubsection{Geographic Dimension}

The geographical distribution of all articles (the address of all authors) is explored, as presented on the maps in Figures 6-9.

Papers that investigated the evaluation indicators of the transport system were predominantly authored by European researchers (73.4\%), as shown in Figure 6, followed by Asian (28.0\%) and North American scholars (13.7\%). In Europe, the top five productive countries were Italy, Spain, Lithuania, Russia, France, and the United Kingdom of Great Britain and Northern Ireland (UK). The Asian countries of China and India and the American countries of the United States of America (USA), Canada, and Brazil paid the most attention to transport sector assessment. Australia and South Africa led the research in Oceania and African countries. Globally, as depicted in Figure 7, following China ( $14.1 \%$ of the total), the USA (8.1\%), Italy (10.6\%), Spain (5.7\%), and Lithuania (5.5\%) published the most literature on transport system evaluation.

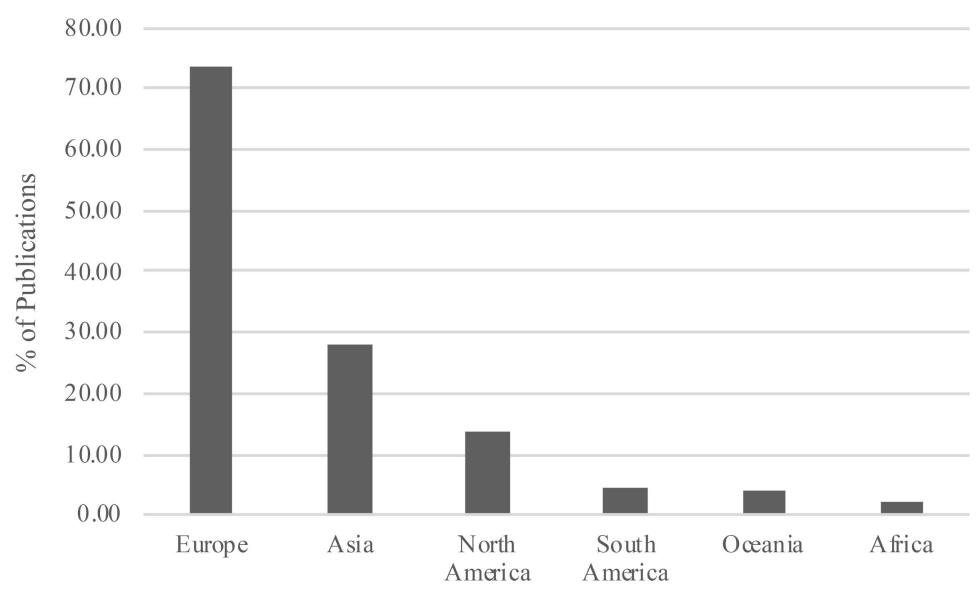

Figure 6. Geographical distribution of research on the topic of transport evaluation indicators (metadata extracted from the address of authors from the records returned from the Web of Science and Scopus databases. Period: 2000-2020 (September)). The number represents the percent of documents published by each continent. 


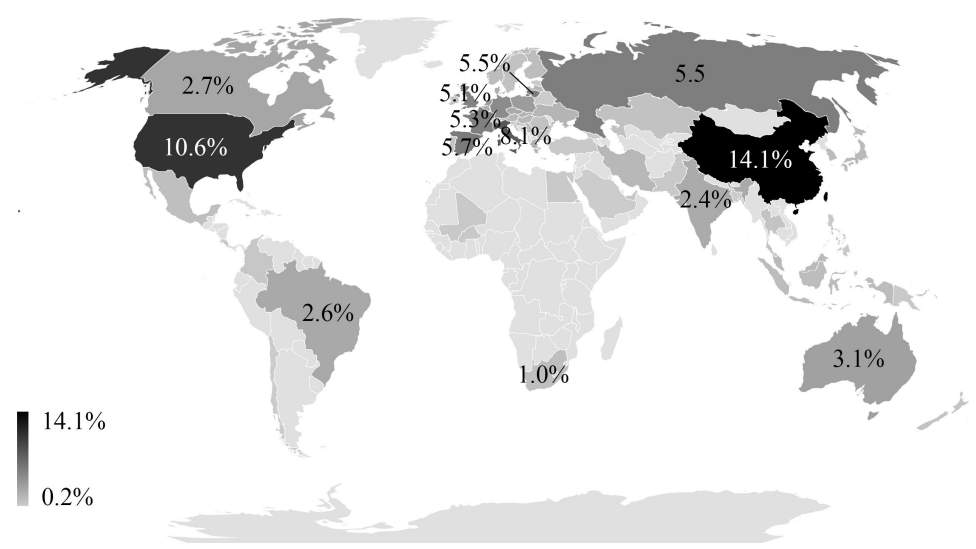

Figure 7. Geographical distribution of research on the topic of transport evaluation indicators (metadata extracted from the address of authors of the records returned from the Web of Science and Scopus databases. Period: 2000-2020 (September)). The number represents the percent of documents published by each country.

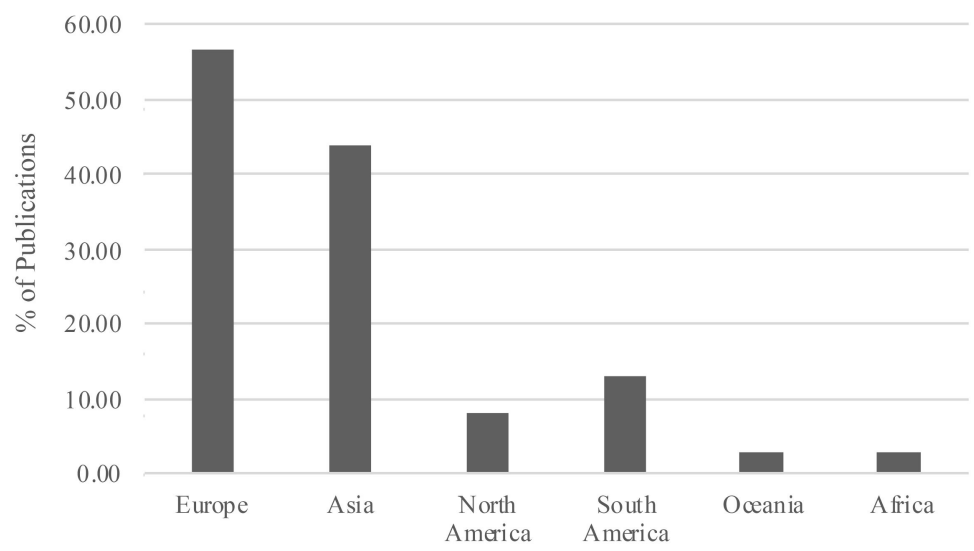

Figure 8. Geographical distribution of research on the topic of public (OR urban) spaces evaluation indicators (metadata extracted from the address of authors from the records returned from the Web of Science and Scopus databases. Period: 2000-2020 (September)). The number represents the percent of documents published by each continent.

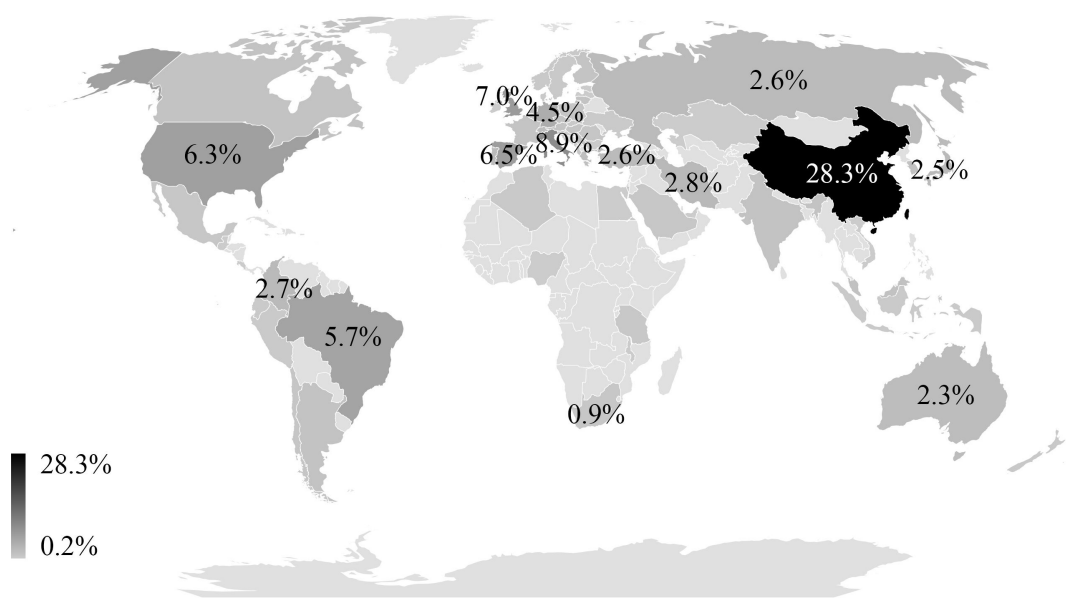

Figure 9. Geographical distribution of research on the topic of public (OR urban) spaces evaluation indicators (metadata extracted from the address of authors from the records returned from the Web of Science and Scopus databases. Period: 2000-2020 (September)). The number represents the percent of documents published by each country. 
Research on evaluation indicators of the public/urban spaces system was mostly reported by European and Asian authors, with $56.5 \%$ and $43.7 \%$ of the total records, respectively (see Figure 8). Italy, the UK, Spain, Germany, and Russia were the most productive European countries, while China, Iran, Turkey, Japan, and South Korea were the most fruitful in Asia. The USA and Brazil produced many more papers than other American countries. On the continents of Oceania and Africa, Australia and South Africa were the main research bodies. Figure 9 maps the dominant countries in examining the indicators for urban and public spaces systems. Among others, China (28.3\%), Italy (8.9\%), Spain $(6.5 \%)$, the USA (6.3\%), and Brazil (5.7\%) rank in the top five.

\subsection{KPI Selection and Indicator Longlisting}

\subsubsection{Keywords and Thematic Data Analysis}

In this work, the frequency of keywords in the study of transport infrastructure and public spaces assessment were analysed and are presented as word clouds in Figures 10a and 11a. These figures also indicate the centrality of each word. Node centrality is a graphical property that quantifies the significance of a point's position in a network, which is usually measured by the betweenness centrality metric. The betweenness centrality of each node is determined by calculating the proportion of total numbers of the shortest paths in a network linking to the node [58]. To further investigate the most common terms used for transport and spaces system evaluation, Figures $10 \mathrm{~b}$ and $11 \mathrm{~b}$ were generated. Here, we excluded any combination of the words used in search strings, i.e., "transport, transportation, infrastructure, evaluation, indicator", which occur repeatedly but are not helpful for extracting themes.

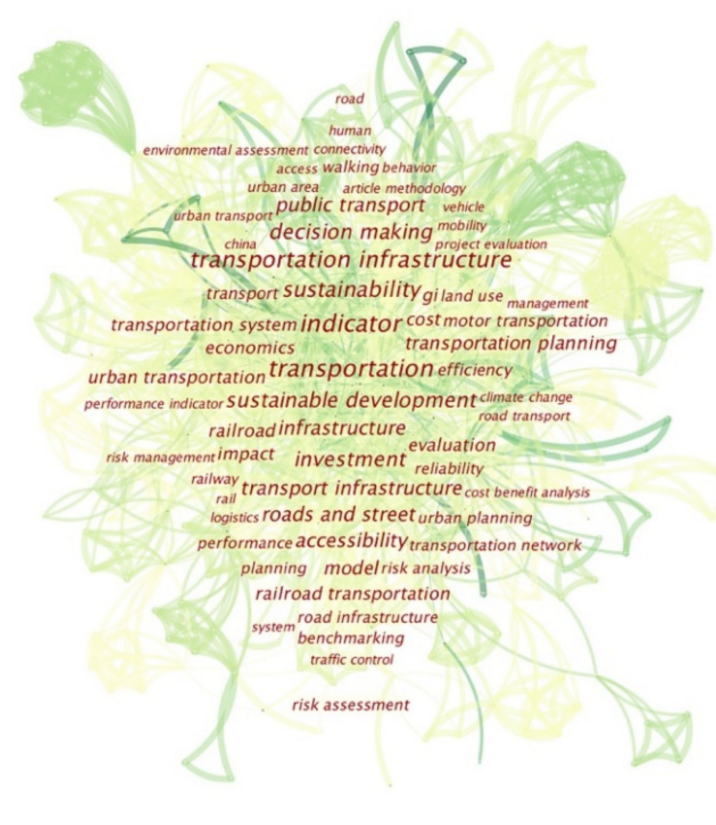

(a)

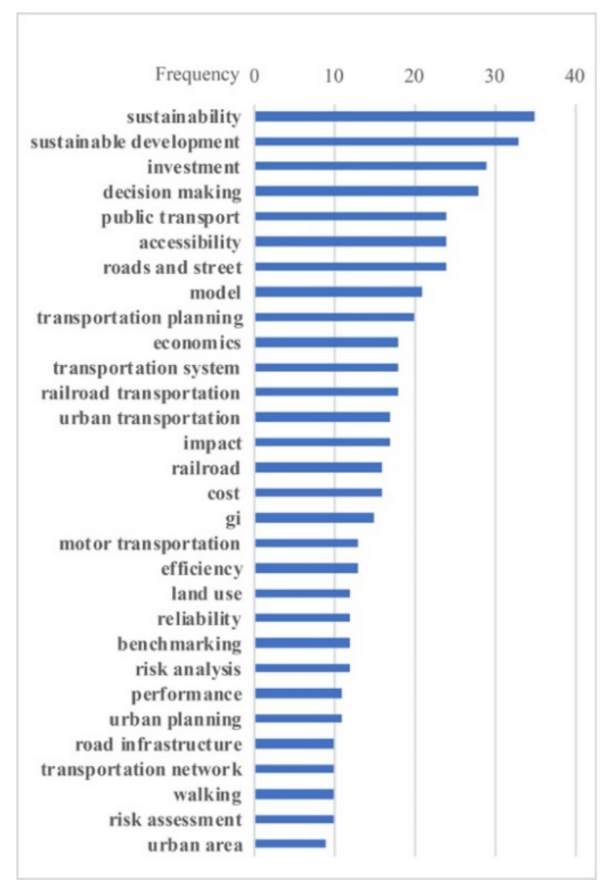

(b)

Figure 10. Frequency analysis of keywords used in research on transport infrastructure evaluation indicators: (a) The bigger the words, the higher the frequency, only showing those occurring more than seven times and (b) the 30 most common words, excluding any combination of the terms in search strings. 


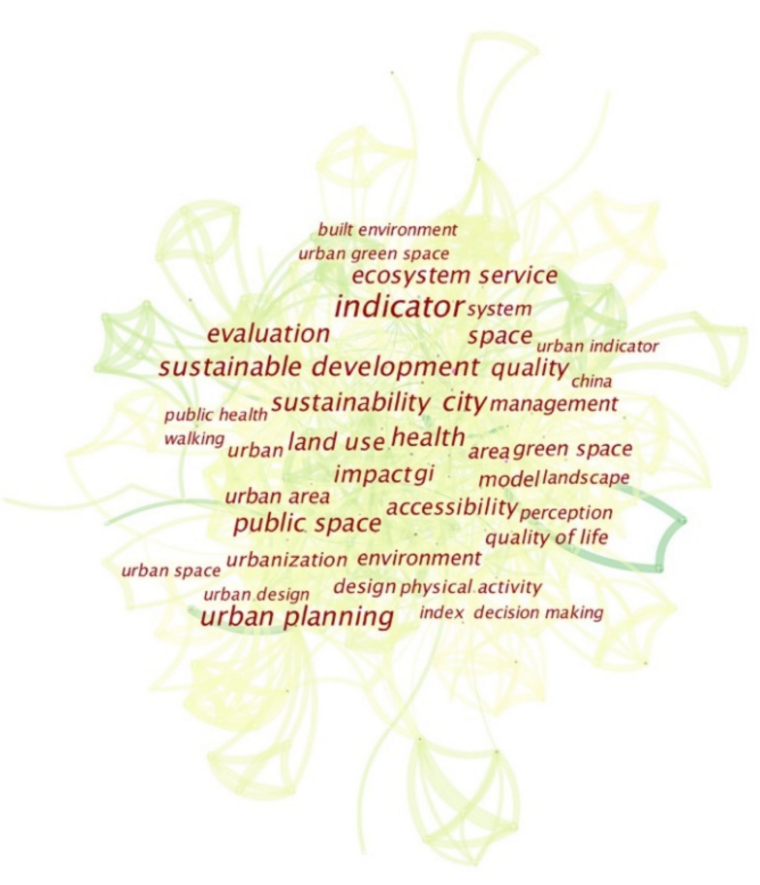

(a)

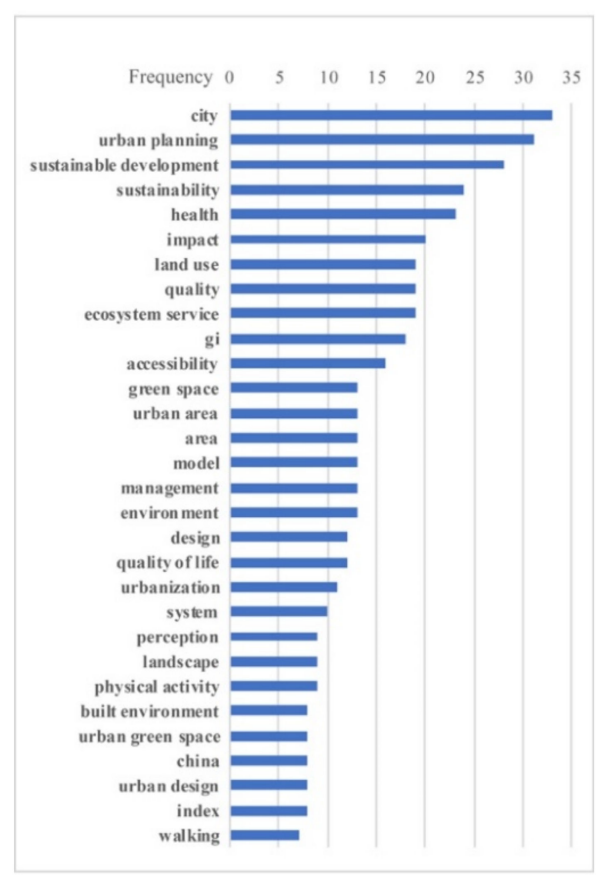

(b)

Figure 11. Frequency analysis of keywords used in research on public/urban spaces evaluation indicators: (a) The bigger the words, the higher the frequency, only showing those occurring more than seven times and (b) the 30 most common words, excluding any combination of the terms in search strings.

It is evident from Figure 10 that the word "sustainability" dominates, appearing 35 times in the publications. "Sustainable development", "investment", "decision making", "public transport", "accessibility", "roads and street", "model", "transportation planning", "economics", "transportation system", "railroad transportation", "urban transportation", "impact", "railroad", "cost", and "green infrastructure" (GI) were utilised frequently (no less than 15 times) in research on transport infrastructure evaluation indicators. In the study on public and urban spaces evaluation indicators (visualised in Figure 11), the terms "city", "urban planning", "sustainability", "sustainable development", "health", "impact", "land use", "quality", "ecosystem service", "green infrastructure" (GI), and "accessibility" each appeared no less than 15 times. This list of keywords is a reference standard for deciding on KPIs. By comparing the two threads of research, we also found that "sustainability (sustainable development)", "accessibility", "impact", and "green infrastructure" are common words utilised in studies of transport and urban spaces evaluation.

Taking into account the list of keywords and the results of the literature content analysis, we chose 22 themes for transportation system evaluation and 15 topics for spaces system evaluation.

\subsubsection{KPIs and Longlisting Indicators Synthesis}

After performing an in-depth review of the documents published since 2009 and an expanded review of influential literature, we completed a meta-analysis, with the results summarised in Table S1 provided in the Supplementary Materials. In consideration of the themes extracted from the previous step, we selected $64 \mathrm{KPIs}$ for assessing transport and spaces systems. Afterwards, a longlist of 124 indicators was chosen for transportation system evaluation, while 113 longlist indicators were decided for spaces system evaluation. Following the goal system of transport-spaces development, the findings were classified into six types: 
(1) Transportation and spaces systems self-performance considering human behaviour;

(2) Transportation and spaces systems performance related to the counterpart system, i.e., where there is a direct interaction between the two systems;

(3) Complementary environmental impacts of the two systems;

(4) Other natural environmental impacts of transportation and spaces systems;

(5) Social impacts; and

(6) Economic impacts.

Figure 12 and Table 1 frame the selected themes and KPIs according to the goal system. Note, however, that the selection and addition of KPIs in realistic projects need to be adjusted regarding certain conditions.

Table 1. The 64 Key Performance Indicators (KPIs) of the transport-spaces system.

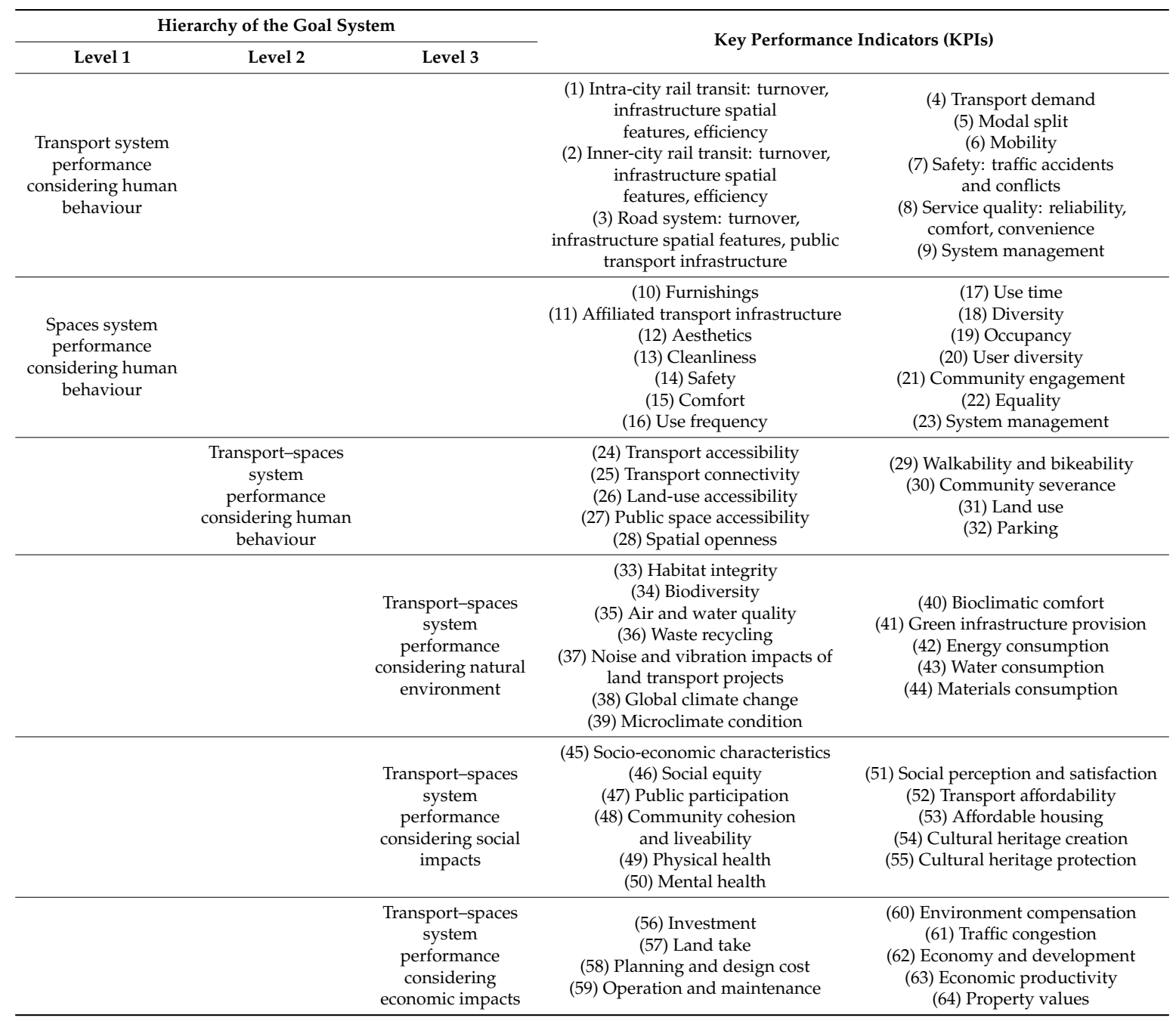


Legend:

T: represents Transport infrastructure

S: represents public Space

H: represents Human behavior

$\mathbf{N}$ : represents Natural environmen

SI: represents Social Impacts

EI: represents Economic Impacts

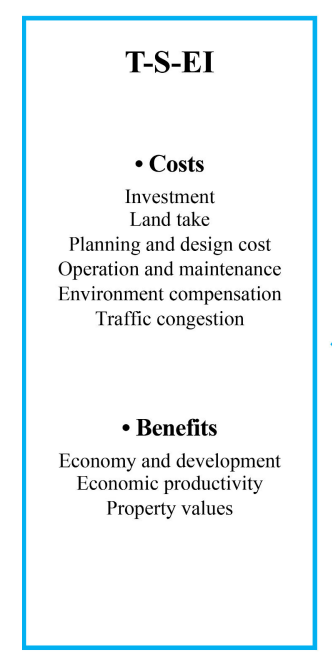

\author{
ture \\ .
}

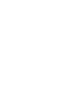

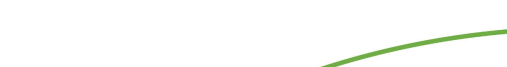

\title{
Notes:
}

Items starting with $\bullet$ are themes

Items without • are KPIs

Figure 12. Themes and Key Performance Indicators (KPIs) used in evaluating the transport infrastructure and urban spaces systems. 


\subsection{Indicator Set Development}

After screening, a total of 117 indicators for transportation infrastructure and 116 indicators for urban spaces systems were selected. Figure 13 maps the number of themes, KPIs, and shortlist indicators introduced to the evaluation of each subsystem.

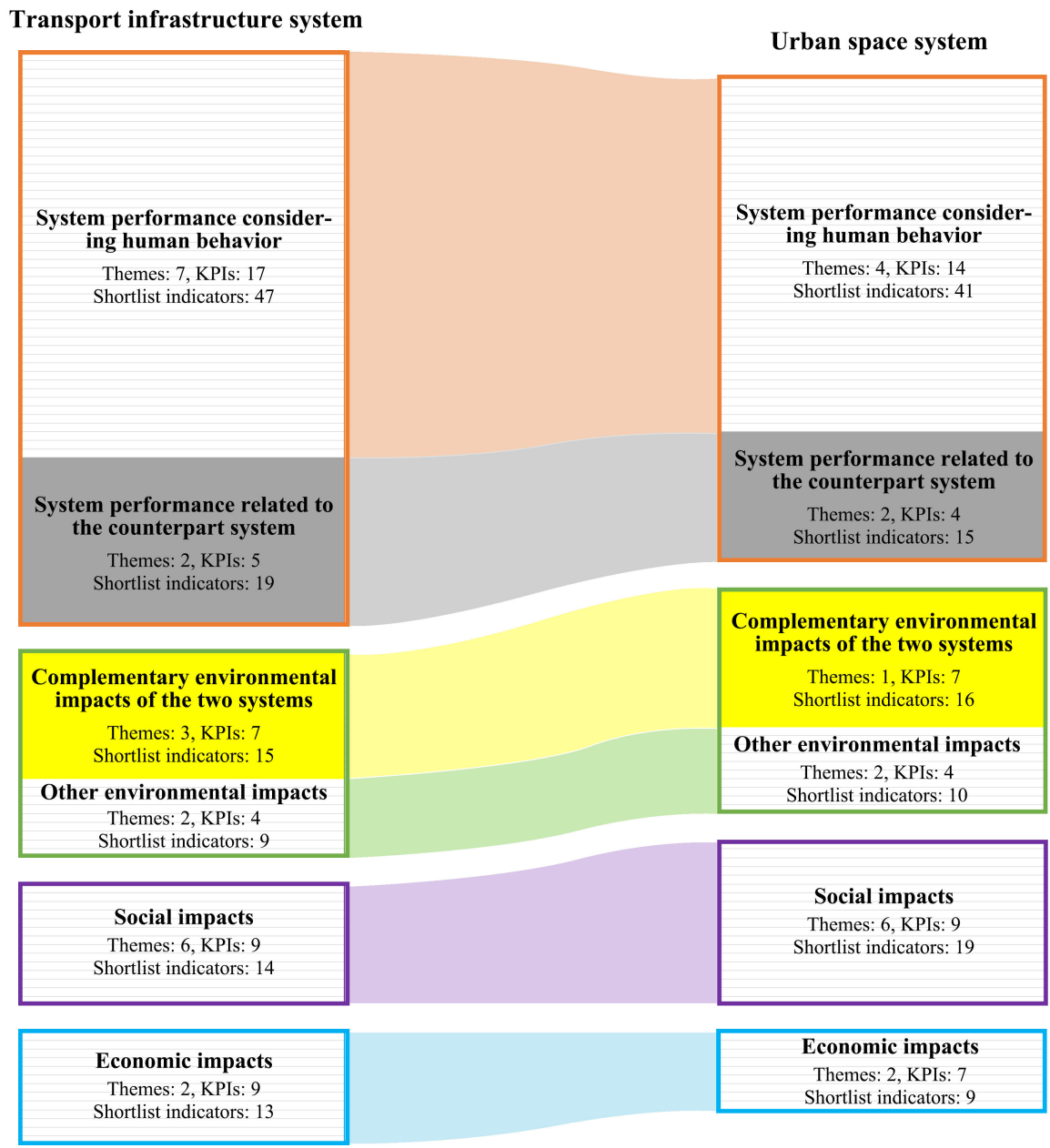

Figure 13. The number of themes, KPIs, and shortlist indicators for different evaluation dimensions. This is a high-level framework of Tables $2-6$ and the meaning of the different colours remains the same as in Figure 12.

In addition, specific explanations and standardisations were performed for each of the selected indicators. For quantitative indicators, the most common units were derived from the literature. Qualitative indicators were marked in the indicator set as well. Afterwards, an initial indicator set was shown to 10 experts in transportation planning, transportation control systems, urban planning, and urban design to collect their comments on each KPI and indicator. We then modified the items and formed the ultimate indicator set for transportation and spaces systems assessment, as shown in Tables 2-6. The indicator system consists of five parts: Part 1 presents the transportation and spaces systems self-performance indicators considering human behaviour, Part 2 shows the performance indicators of transportation and spaces systems that correspond to the counterpart system, and Part 3 lists the environmental impacts of transportation and spaces systems in which the complementary effects of the two systems were highlighted. Part 4 and Part 5 denote the social and economic impacts of the systems. Note that the Explanations column in these figures either describes the meaning of an indicator (by providing a definition, illustrating the evaluation objective, or giving an example) or demonstrates a common way to measure an indicator. 
Table 2. An indicator set for evaluating the transport and spaces systems-Part 1: The transportation and spaces systems self-performance indicators considering human behaviour (further details see the Supplementary Materials).

\begin{tabular}{|c|c|c|c|c|c|c|c|c|}
\hline \multicolumn{4}{|c|}{ Transport infrastructure system } & \multicolumn{5}{|c|}{ Urban space system } \\
\hline Theme & KPI & Indicator & Explanation & Theme & KPI & Indicator & Explanation & Unit \\
\hline \multirow{12}{*}{$\begin{array}{l}\text { Intra-city rail } \\
\text { transit system } \\
\text { (railway) }\end{array}$} & \multirow{2}{*}{ Turnover } & Number of passengers & $\begin{array}{c}\text { million } \\
\text { people/d }\end{array}$ & \multirow{17}{*}{$\begin{array}{l}\text { Quality } \\
\text { (physical } \\
\text { setting) }\end{array}$} & \multirow{4}{*}{ Furnishings } & Pavement materials quality & & Qual \\
\hline & & Number of goods & tons/d & & & $\begin{array}{l}\text { Share of vandal-proof } \\
\text { materials usage }\end{array}$ & & \\
\hline & \multirow{6}{*}{$\begin{array}{l}\text { Infrastructure } \\
\text { spatial } \\
\text { features }\end{array}$} & $\begin{array}{l}\text { Length of operational } \\
\text { rail lines }\end{array}$ & $\mathrm{km}$ & & & Bike racks provision & & racks \\
\hline & & Network density & $\mathrm{km} / \mathrm{km}^{2}$ & & & Seating furniture provision & & seats \\
\hline & & Network extension & $\%$ & & \multirow{2}{*}{$\begin{array}{c}\text { Affiliated } \\
\text { transport } \\
\text { infrastructure }\end{array}$} & $\begin{array}{l}\text { Quality of the structure of } \\
\text { the transport infrastructure }\end{array}$ & & Qual \\
\hline & & Population influenced & $\mathrm{km} /$ capita & & & $\begin{array}{l}\text { Quality of materials of } \\
\text { the transport infrastructure }\end{array}$ & & Qual \\
\hline & & $\begin{array}{l}\text { Ratio of electrified } \\
\text { railways }\end{array}$ & $\%$ & & & Imageability & & Qual \\
\hline & & Ratio of high-speed rail & $\%$ & & & Identity (or sense of belonging) & & Qual \\
\hline & \multirow{4}{*}{ Efficiency } & $\begin{array}{l}\text { Occupancy rate of } \\
\text { vehicles }\end{array}$ & passengers $/ \mathrm{km}$ & & & Public art presence & & Qual \\
\hline & & Frequency & trains/d & & Aesthetics & $\begin{array}{l}\text { Landscape topography-spatial } \\
\text { arrangement on different } \\
\text { elevations }\end{array}$ & & Qual \\
\hline & & $\begin{array}{l}\text { Workers in this } \\
\text { infrastructure }\end{array}$ & population & & & View value & & Qual \\
\hline & & Number of locomotives & locomotives/y & & & Shadow & $\begin{array}{l}\text { Average area } \\
\text { of the shadow }\end{array}$ & $\mathrm{m}^{2}$ \\
\hline \multirow{5}{*}{$\begin{array}{l}\text { Inner-city rail } \\
\text { transit system } \\
\text { (light rail } \\
\text { and tram) }\end{array}$} & $\begin{array}{l}\text { Turnover (by } \\
\text { each mode) }\end{array}$ & Number of passengers & $\begin{array}{l}\text { million } \\
\text { people/d }\end{array}$ & & \multirow{3}{*}{ Cleanness } & Washing and sweeping & & Qual \\
\hline & \multirow{4}{*}{$\begin{array}{c}\text { Infrastructure } \\
\text { spatial } \\
\text { features (by } \\
\text { each mode) }\end{array}$} & $\begin{array}{c}\text { Length of total } \\
\text { operational rail lines }\end{array}$ & $\mathrm{km}$ & & & Garbage disposal & & Qual \\
\hline & & Network density & $\mathrm{km} / \mathrm{km}^{2}$ & & & $\begin{array}{l}\text { The ratio of the number of } \\
\text { buildings with graffiti }\end{array}$ & & $\%$ \\
\hline & & Network extension & $\%$ & & \multirow{2}{*}{ Safety } & Effective and correct lighting & & Qual \\
\hline & & Population influenced & $\mathrm{km} / \mathrm{capita}$ & & & Use at all hours of the day & & $\mathrm{h} / \mathrm{d}$ \\
\hline
\end{tabular}


Table 2. Cont.

\begin{tabular}{|c|c|c|c|c|c|c|c|c|c|}
\hline \multicolumn{5}{|c|}{ Transport infrastructure system } & \multicolumn{5}{|c|}{ Urban space system } \\
\hline Theme & KPI & Indicator & Explanation & Unit & Theme & KPI & Indicator & Explanation & Unit \\
\hline \multirow{3}{*}{$\begin{array}{l}\text { Inner-city rail } \\
\text { transit system } \\
\text { (light rail } \\
\text { and tram) }\end{array}$} & \multirow{3}{*}{$\begin{array}{l}\text { Efficiency (of } \\
\text { each mode) }\end{array}$} & $\begin{array}{l}\text { Occupancy rate of } \\
\text { vehicles }\end{array}$ & & passengers $/ \mathrm{km}$ & \multirow{10}{*}{$\begin{array}{c}\text { Quality } \\
\text { (physical } \\
\text { setting) }\end{array}$} & \multirow{8}{*}{ Safety } & $\begin{array}{l}\text { The average number of } \\
\text { passers-by }\end{array}$ & & passers-by \\
\hline & & Frequency & & trains/d & & & $\begin{array}{l}\text { The presence of policies/CCTVs } \\
\text { on a street }\end{array}$ & & $\begin{array}{l}\text { policies } \\
\text { (OR } \\
\text { CCTVs) }\end{array}$ \\
\hline & & $\begin{array}{l}\text { Workers in this } \\
\text { infrastructure }\end{array}$ & & population & & & $\begin{array}{l}\text { Protection against vehicular } \\
\text { traffic }\end{array}$ & $\begin{array}{l}\text { e.g., Traffic } \\
\text { speed } \\
\text { reducers } \\
\text { provision }\end{array}$ & Qual \\
\hline \multirow{8}{*}{ Road system } & \multirow[t]{2}{*}{ Turnover } & Number of passengers & & $\begin{array}{l}\text { million } \\
\text { people/d }\end{array}$ & & & $\begin{array}{l}\text { Protection against unpleasant } \\
\text { sensory experiences }\end{array}$ & & Qual \\
\hline & & Number of goods & & tons/d & & & Number of crimes per year & & crimes/y \\
\hline & \multirow{3}{*}{$\begin{array}{c}\text { Infrastructure } \\
\text { spatial } \\
\text { features }\end{array}$} & $\begin{array}{l}\text { Length of total } \\
\text { operational roads }\end{array}$ & & $\mathrm{km}$ & & & Emergency plans & & Qual \\
\hline & & $\begin{array}{l}\text { Ratio of modern } \\
\text { roadways }\end{array}$ & & $\%$ & & & $\begin{array}{l}\text { Security protection for crowd } \\
\text { cluster }\end{array}$ & & Qual \\
\hline & & Network density & & $\mathrm{km} / \mathrm{km}^{2}$ & & & Protection from natural disaster & & Qual \\
\hline & \multirow{3}{*}{$\begin{array}{c}\text { Public } \\
\text { transport } \\
\text { infrastructure }\end{array}$} & Public transport stops & $\begin{array}{c}\text { Further } \\
\text { measured by } \\
\text { passenger } \\
\text { shelter, } \\
\text { cleanness, } \\
\text { seats, lighting, } \\
\text { CCTV, } \\
\text { timetable, } \\
\text { real-time } \\
\text { display, Wi-Fi, } \\
\text { etc. }\end{array}$ & - & & \multirow[t]{2}{*}{ Comfort } & $\begin{array}{l}\text { Feeling of psychological comfort } \\
\text { of users }\end{array}$ & & Qual \\
\hline & & $\begin{array}{l}\text { Public transport route } \\
\text { network }\end{array}$ & $\begin{array}{l}\text { Further } \\
\text { measured by } \\
\text { multimodal } \\
\text { compatibility, } \\
\text { the system of } \\
\text { ticket sale } \\
\text { and distribution, } \\
\text { distance to } \\
\text { a bus stop, etc. }\end{array}$ & - & & & $\begin{array}{l}\text { Connections with devices such } \\
\text { as ramps, elevators, etc. }\end{array}$ & & - \\
\hline & & $\begin{array}{l}\text { Public transport } \\
\text { efficiency }\end{array}$ & $\begin{array}{l}\text { Occupancy } \\
\text { rate of buses }\end{array}$ & $\%$ & Usage & Use frequency & $\begin{array}{l}\text { Average time occupied by users } \\
\text { within a day, a week }\end{array}$ & & $\begin{array}{l}\text { h/d (OR } \\
\text { h/week) }\end{array}$ \\
\hline
\end{tabular}


Table 2. Cont.

\begin{tabular}{|c|c|c|c|c|c|c|c|c|c|}
\hline \multicolumn{5}{|c|}{ Transport infrastructure system } & \multicolumn{5}{|c|}{ Urban space system } \\
\hline Theme & KPI & Indicator & Explanation & Unit & Theme & KPI & Indicator & Explanation & Unit \\
\hline \multirow{7}{*}{$\begin{array}{c}\text { Travel } \\
\text { behaviour }\end{array}$} & \multirow{2}{*}{$\begin{array}{l}\text { Transport } \\
\text { demand }\end{array}$} & $\begin{array}{l}\text { Non-motorized } \\
\text { transport demand }\end{array}$ & & $\begin{array}{l}\text { passenger-km } \\
\text { travelled }\end{array}$ & \multirow{3}{*}{ Usage } & Use time & $\begin{array}{c}\text { Time used for medium or } \\
\text { vigorous physical activity per } \\
\text { day }\end{array}$ & & $\mathrm{h} / \mathrm{d}$ \\
\hline & & $\begin{array}{l}\text { Motorized transport } \\
\text { demand }\end{array}$ & & $\begin{array}{l}\text { vehicle-km } \\
\text { travelled }\end{array}$ & & \multirow[b]{2}{*}{ Diversity } & $\begin{array}{l}\text { Density of public services within } \\
\text { all area }\end{array}$ & & services $/ \mathrm{m}^{2}$ \\
\hline & \multirow[t]{2}{*}{ Modal split } & $\begin{array}{l}\text { Personal travel mode } \\
\text { split }\end{array}$ & $\begin{array}{l}\text { Share of } \\
\text { non-motorized, } \\
\text { automobile, } \\
\text { public } \\
\text { transport }\end{array}$ & - & & & Variety of activity types & & - \\
\hline & & Freight mode split & $\begin{array}{l}\text { Share of truck, } \\
\text { rail, ship, air }\end{array}$ & - & \multirow{8}{*}{ Users } & \multirow[b]{2}{*}{ Occupancy } & Number of users & & users \\
\hline & \multirow{3}{*}{ Mobility } & $\begin{array}{l}\text { Average person-miles } \\
\text { or trips per day or per } \\
\text { year }\end{array}$ & & $\begin{array}{c}\text { person-km/d } \\
(\mathrm{OR} \\
\text { person-trips/y) }\end{array}$ & & & $\begin{array}{l}\text { Concentration of residents } \\
\text { and their financial status within } \\
\text { 15-min walking, cycling, } \\
\text { and car-driving }\end{array}$ & & population \\
\hline & & $\begin{array}{l}\text { Average commute } \\
\text { travel time }\end{array}$ & & $\mathrm{h} / \mathrm{d}$ & & \multirow{3}{*}{ User diversity } & $\begin{array}{l}\text { Mix of different household } \\
\text { income users }\end{array}$ & & - \\
\hline & & $\begin{array}{l}\text { Average transport } \\
\text { speed }\end{array}$ & & $\mathrm{km} / \mathrm{h}$ & & & $\begin{array}{l}\text { Mix of users from different } \\
\text { educational attainment }\end{array}$ & & - \\
\hline \multirow{4}{*}{ Safety } & \multirow[b]{2}{*}{$\begin{array}{c}\text { Traffic } \\
\text { accidents }\end{array}$} & $\begin{array}{l}\text { Annual number of } \\
\text { traffic crashes } \\
\text { and fatalities per } \\
100,000 \text { residents }\end{array}$ & & $\begin{array}{l}\text { accidents } / 100,000 \\
\text { residents }\end{array}$ & & & $\begin{array}{c}\text { Mix of users from different races } \\
\text { and ethnicities }\end{array}$ & & - \\
\hline & & $\begin{array}{l}\text { Share of population } \\
\text { feeling safe from } \\
\text { violations and other } \\
\text { relevant incidents } \\
\text { during traveling }\end{array}$ & & Qual & & $\begin{array}{l}\text { Community } \\
\text { engagement }\end{array}$ & $\begin{array}{l}\text { Degree to which the public is } \\
\text { involved in public space design } \\
\text { process }\end{array}$ & & Qual \\
\hline & \multirow{2}{*}{$\begin{array}{l}\text { Traffic } \\
\text { conflicts }\end{array}$} & $\begin{array}{l}\text { Number of collisions } \\
\text { between motor vehicles } \\
\text { and non-motorized } \\
\text { travellers }\end{array}$ & & collisions & & \multirow[b]{2}{*}{ Equality } & $\begin{array}{l}\text { Degree to which vulnerable } \\
\text { people's needs are considered in } \\
\text { public space design }\end{array}$ & & Qual \\
\hline & & $\begin{array}{l}\text { Number of collisions } \\
\text { between pedestrians } \\
\text { and vehicles }\end{array}$ & & collisions & & & $\begin{array}{l}\text { Degree to which used by specific } \\
\text { social groups (homeless etc.) }\end{array}$ & & Qual \\
\hline
\end{tabular}


Table 2. Cont

\begin{tabular}{|c|c|c|c|c|c|c|c|c|c|}
\hline \multicolumn{5}{|c|}{ Transport infrastructure system } & \multicolumn{5}{|c|}{ Urban space system } \\
\hline Theme & KPI & Indicator & Explanation & Unit & Theme & KPI & Indicator & Explanation & Unit \\
\hline \multirow{4}{*}{$\begin{array}{l}\text { Service } \\
\text { quality }\end{array}$} & \multicolumn{3}{|l|}{ Reliability } & Qual & \multirow{7}{*}{$\begin{array}{c}\text { System } \\
\text { management }\end{array}$} & \multirow{7}{*}{$\begin{array}{l}\text { Public space } \\
\text { system } \\
\text { management }\end{array}$} & $\begin{array}{l}\text { Degree of multi-stakeholder } \\
\text { cooperation }\end{array}$ & & Qual \\
\hline & & $\begin{array}{l}\text { Integration of different } \\
\text { transport modes }\end{array}$ & & Qual & & & \multirow{6}{*}{ Maintenance of public space } & & \multirow{6}{*}{ Qual } \\
\hline & $\begin{array}{l}\text { Comfort and } \\
\text { convenience }\end{array}$ & $\begin{array}{c}\text { Quality of } \\
\text { non-automobile modes } \\
\text { relative to } \\
\text { automobile travel }\end{array}$ & & Qual & & & & & \\
\hline & & $\begin{array}{l}\text { Quality of transport for } \\
\text { vulnerable people }\end{array}$ & & Qual & & & & & \\
\hline \multirow{3}{*}{$\begin{array}{c}\text { System } \\
\text { management }\end{array}$} & \multirow{3}{*}{$\begin{array}{c}\text { Traffic } \\
\text { management }\end{array}$} & $\begin{array}{l}\text { Traffic regulation } \\
\text { management }\end{array}$ & & Qual & & & & & \\
\hline & & $\begin{array}{c}\text { Intelligent } \\
\text { transportation system }\end{array}$ & & Qual & & & & & \\
\hline & & Traffic facilities & $\begin{array}{c}\text { Further } \\
\text { measured by } \\
\text { traffic signals, } \\
\text { traffic signs, } \\
\text { road marking }\end{array}$ & Qual & & & & & \\
\hline
\end{tabular}

Note: 'Qual' represents qualitative indicators.

Table 3. An indicator set for evaluating the transport and spaces systems-Part 2: The transportation and spaces systems performance indicators related to the counterpart system (further details see the Supplementary Materials).

\begin{tabular}{|c|c|c|c|c|c|c|c|c|c|}
\hline \multicolumn{5}{|c|}{ Transport Infrastructure System } & \multicolumn{5}{|c|}{ Urban Space System } \\
\hline Theme & KPI & Indicator & Explanation & Unit & Theme & KPI & Indicator & Explanation & Unit \\
\hline \multirow{3}{*}{ Accessibility } & \multirow{2}{*}{$\begin{array}{l}\text { Transport } \\
\text { accessibility }\end{array}$} & $\begin{array}{c}\text { Share of population living within } \\
300-500 \mathrm{~m} \text { from public } \\
\text { transport stations }\end{array}$ & & population & \multirow{3}{*}{ Access } & \multirow{3}{*}{$\begin{array}{l}\text { Public space } \\
\text { accessibility }\end{array}$} & $\begin{array}{l}\text { Accessibility } \\
\text { by walking }\end{array}$ & & - \\
\hline & & $\begin{array}{l}\text { Ratio between number of } \\
\text { stations and the reference } \\
\text { territory surface }\end{array}$ & & stations $/ \mathrm{km}^{2}$ & & & Accessibility by cycling & & 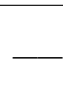 \\
\hline & $\begin{array}{c}\text { Transport } \\
\text { connectivity }\end{array}$ & Connected Node Ratio (CNR) & & $\%$ & & & $\begin{array}{l}\text { Accessibility to public } \\
\text { transport station }\end{array}$ & & $\longrightarrow$ \\
\hline
\end{tabular}


Table 3. Cont.

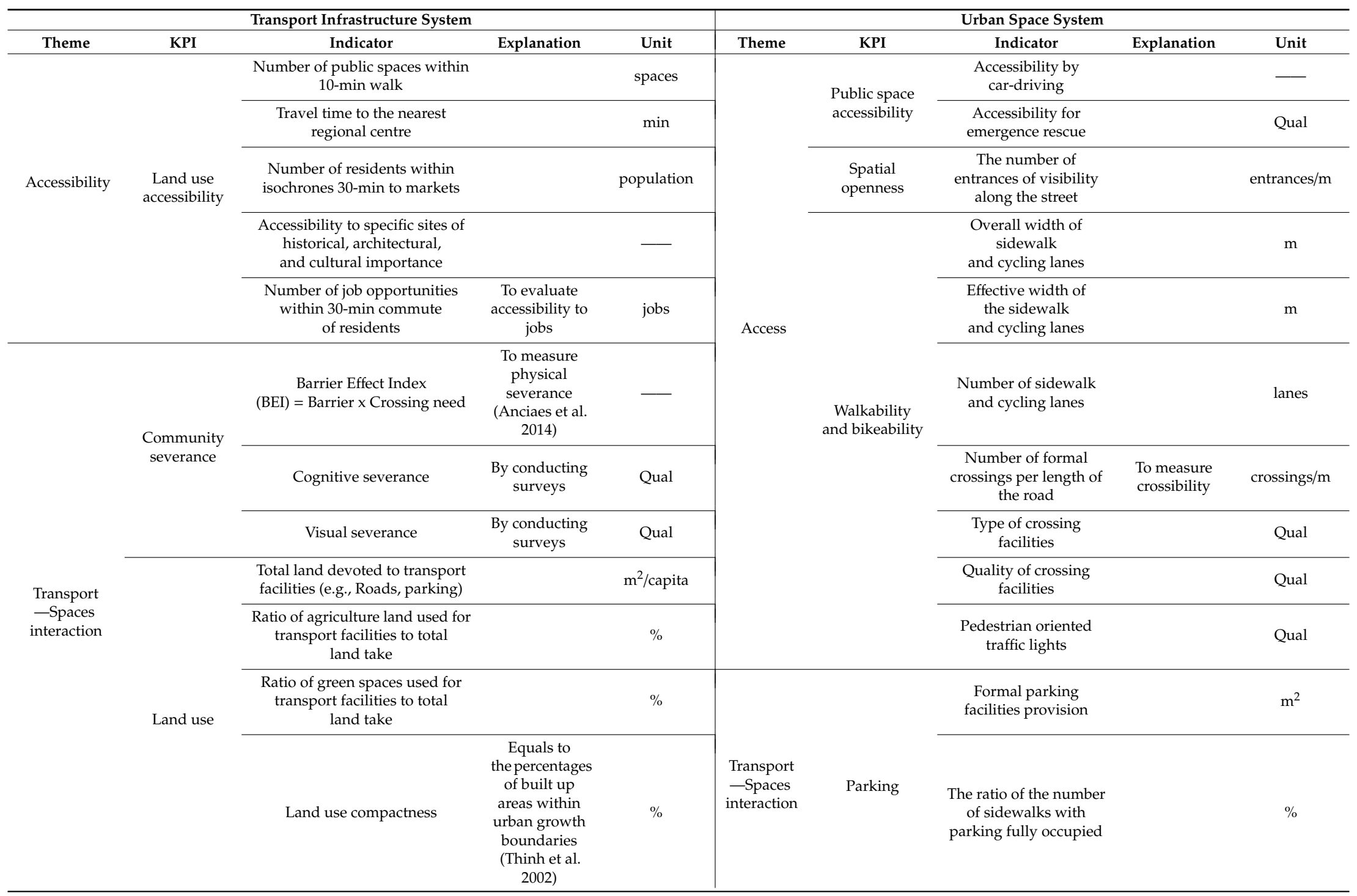


Table 3. Cont.

\begin{tabular}{|c|c|c|c|c|c|c|c|c|c|}
\hline \multicolumn{5}{|c|}{ Transport Infrastructure System } & \multicolumn{5}{|c|}{ Urban Space System } \\
\hline Theme & KPI & Indicator & Explanation & Unit & Theme & KPI & Indicator & Explanation & Unit \\
\hline \multirow{4}{*}{$\begin{array}{l}\text { Transport } \\
\text { - Spaces } \\
\text { interaction }\end{array}$} & \multirow{4}{*}{ Land use } & Population density & & population $/ \mathrm{m}^{2}$ & & & & & \\
\hline & & Development location & & Qual & & & & & \\
\hline & & Regeneration of brownfield sites & & Qual & & & & & \\
\hline & & $\begin{array}{l}\text { Preservation of specific sites of } \\
\text { historical, architectural, } \\
\text { and cultural importance }\end{array}$ & & Qual & & & & & \\
\hline
\end{tabular}

Table 4. An indicator set for evaluating the transport and spaces systems-Part 3: Items highlighted in yellow denote the complementary impacts of the two systems, while other items illustrate the other natural environmental impacts of the systems (further details see the Supplementary Materials).

\begin{tabular}{|c|c|c|c|c|c|c|c|c|c|}
\hline \multicolumn{5}{|c|}{ Transport Infrastructure System } & \multicolumn{5}{|c|}{ Urban Space System } \\
\hline Theme & KPI & Indicator & Explanation & Unit & Theme & KPI & Indicator & Explanation & Unit \\
\hline \multirow{6}{*}{$\begin{array}{l}\text { Eco-system } \\
\text { health }\end{array}$} & \multirow{2}{*}{$\begin{array}{l}\text { Habitat } \\
\text { integrity }\end{array}$} & $\begin{array}{l}\text { Habitat Connectivity } \\
\text { Index }(\mathrm{CI})\end{array}$ & $\begin{array}{c}\text { To measure habitat } \\
\text { fragmentation } \\
\text { degree (Hanski } \\
\text { 1994) }\end{array}$ & - & \multirow{6}{*}{$\begin{array}{l}\text { Eco-system } \\
\text { health }\end{array}$} & & Habitat animals & $\begin{array}{l}\text { Provision of living } \\
\text { space that support } \\
\text { species richness for } \\
\text { animals }\end{array}$ & $\mathrm{m}^{2}$ \\
\hline & & $\begin{array}{l}\text { Annual number of } \\
\text { collisions with wildlife }\end{array}$ & & collisions & & $\begin{array}{l}\text { Habitat } \\
\text { integrity }\end{array}$ & Habitat plants & $\begin{array}{l}\text { Provision of living } \\
\text { space that support } \\
\text { species richness for } \\
\text { plants }\end{array}$ & $\mathrm{m}^{2}$ \\
\hline & \multirow[b]{2}{*}{ Biodiversity } & Species loss rate & $\begin{array}{l}\text { Variation of species } \\
\text { richness overtime }\end{array}$ & - & & & Plant pollination & $\begin{array}{l}\text { Provision of plant } \\
\text { pollination }\end{array}$ & Qual \\
\hline & & $\begin{array}{c}\text { Number of endangered } \\
\text { species }\end{array}$ & & - & & \multirow[t]{2}{*}{ Biodiversity } & $\begin{array}{c}\text { Species richness. } \\
\text { Menhinick's index } \\
\mathrm{D}=\text { number of different } \\
\text { species/total number of } \\
\text { individual organisms in } \\
\text { the sample }\end{array}$ & & $\%$ \\
\hline & \multirow{2}{*}{$\begin{array}{l}\text { Air and water } \\
\text { pollution }\end{array}$} & $\begin{array}{l}\text { Traffic air pollutant } \\
\text { emissions }\end{array}$ & $\begin{array}{l}\text { To measure } \\
\text { traffic-related air } \\
\text { pollution }\end{array}$ & $\mu \mathrm{g} /$ capita & & & $\begin{array}{c}\text { Protection of } \\
\text { endangered species }\end{array}$ & & Qual \\
\hline & & $\begin{array}{l}\text { Concentration of air } \\
\text { pollutant emissions }\end{array}$ & & $\mu \mathrm{g} / \mathrm{m}^{3}$ & & $\begin{array}{l}\text { Air and water } \\
\text { quality }\end{array}$ & $\begin{array}{l}\text { Concentration of air } \\
\text { pollutant emissions } \\
\text { (NOx, CO, PM, etc.) }\end{array}$ & $\begin{array}{l}\text { To measure air } \\
\text { purification } \\
\text { effectiveness }\end{array}$ & $\mu \mathrm{g} / \mathrm{m}^{3}$ \\
\hline
\end{tabular}


Table 4. Cont.

\begin{tabular}{|c|c|c|c|c|c|c|c|c|c|}
\hline \multicolumn{5}{|c|}{ Transport Infrastructure System } & \multicolumn{5}{|c|}{ Urban Space System } \\
\hline Theme & KPI & Indicator & Explanation & Unit & Theme & KPI & Indicator & Explanation & Unit \\
\hline \multirow{7}{*}{$\begin{array}{l}\text { Eco-system } \\
\text { health }\end{array}$} & \multirow[t]{2}{*}{$\begin{array}{l}\text { Air and water } \\
\text { pollution }\end{array}$} & $\begin{array}{l}\mathrm{pH} \text {; temperature; } \\
\text { chlorophyll } \\
\text { fluorescence; total } \\
\text { solids; conductivity } \\
\text { and alkalinity; } \\
\text { dissolved oxygen } \\
\text { levels; total hardness }\end{array}$ & $\begin{array}{c}\text { To measure } \\
\text { transport-related } \\
\text { water pollution }\end{array}$ & - & \multirow{4}{*}{$\begin{array}{l}\text { Eco-system } \\
\text { health }\end{array}$} & $\begin{array}{l}\text { Air and water } \\
\text { quality }\end{array}$ & $\begin{array}{c}\mathrm{pH} \text {; temperature; } \\
\text { chlorophyll } \\
\text { fluorescence; total } \\
\text { solids; conductivity } \\
\text { and alkalinity; } \\
\text { dissolved oxygen } \\
\text { levels; total hardness }\end{array}$ & $\begin{array}{l}\text { To measure water } \\
\text { purification } \\
\text { effectiveness }\end{array}$ & - \\
\hline & & $\begin{array}{c}\text { Transport } \\
\text { infrastructure } \\
\text { impervious area per } \\
\text { capita }\end{array}$ & $\begin{array}{l}\text { To measure water } \\
\text { run-off }\end{array}$ & $\mathrm{m}^{2} /$ capita & & \multirow{2}{*}{$\begin{array}{l}\text { Waste } \\
\text { recycling }\end{array}$} & \multicolumn{2}{|l|}{$\begin{array}{l}\text { Waste decomposition } \\
\text { effectiveness }\end{array}$} & - \\
\hline & \multirow{2}{*}{$\begin{array}{c}\text { Waste } \\
\text { disposal } \\
\text { and recycling }\end{array}$} & \multicolumn{2}{|l|}{$\begin{array}{l}\text { Transport solid waste } \\
\text { per capita }\end{array}$} & $\mathrm{kg} /$ capita & & & \multicolumn{2}{|l|}{$\begin{array}{l}\text { Construction waste } \\
\text { reused or recycle in-situ } \\
\text { in respect to total waste } \\
\text { production }\end{array}$} & $\mathrm{kg} / \mathrm{m}^{2}$ \\
\hline & & \multicolumn{2}{|l|}{$\begin{array}{l}\text { Recycling rate for } \\
\text { end-of-life vehicles }\end{array}$} & $\%$ & & $\begin{array}{c}\text { Noise } \\
\text { and vibrant } \\
\text { control }\end{array}$ & Noise levels & & $\mathrm{dB}$ \\
\hline & $\begin{array}{l}\text { Noise } \\
\text { pollution }\end{array}$ & \multicolumn{2}{|l|}{ Traffic noise pollution } & decibel & \multirow{5}{*}{$\begin{array}{l}\text { Climate } \\
\text { condition }\end{array}$} & \multirow{3}{*}{$\begin{array}{l}\text { Microclimate } \\
\text { mitigation }\end{array}$} & \multicolumn{2}{|l|}{ Air temperature } & ${ }^{\circ} \mathrm{C}$ \\
\hline & \multirow{2}{*}{$\begin{array}{l}\text { Dust } \\
\text { and vibration } \\
\text { impacts }\end{array}$} & $\begin{array}{l}\text { Vibration impacts of } \\
\text { land transport projects }\end{array}$ & & $\mathrm{Hz}$ & & & $\begin{array}{l}\text { Mean radiation } \\
\text { temperature }\end{array}$ & & ${ }^{\circ} \mathrm{C}$ \\
\hline & & Dust pollution & & - & & & Wind speed & & $\mathrm{m} / \mathrm{s}$ \\
\hline \multirow{2}{*}{$\begin{array}{l}\text { Climate } \\
\text { condition }\end{array}$} & \multirow{2}{*}{$\begin{array}{l}\text { Global climate } \\
\text { change }\end{array}$} & GHG emissions & & $\mathrm{kg} /$ capita & & \multirow{2}{*}{$\begin{array}{l}\text { Bioclimatic } \\
\text { comfort }\end{array}$} & \multirow{2}{*}{ Thermal comfort } & $\begin{array}{l}\text { Spatial distribution of } \\
\text { daytime thermal } \\
\text { comfort on } \\
\text { a summer day }\end{array}$ & $\%$ and ${ }^{\circ} \mathrm{C}$ \\
\hline & & $\begin{array}{l}\text { Electromagnetic } \\
\text { radiation }\end{array}$ & & $\begin{array}{l}\text { milligauss } \\
\quad(\mathrm{mG})\end{array}$ & & & & $\begin{array}{l}\text { Annual frequency of } \\
\text { thermal comfort for } \\
\text { the point with worst } \\
\text { microclimatic } \\
\text { conditions }\end{array}$ & $\%$ and ${ }^{\circ} \mathrm{C}$ \\
\hline
\end{tabular}


Table 4. Cont.

\begin{tabular}{|c|c|c|c|c|c|c|c|c|c|}
\hline \multicolumn{5}{|c|}{ Transport Infrastructure System } & \multicolumn{5}{|c|}{ Urban Space System } \\
\hline Theme & KPI & Indicator & Explanation & Unit & Theme & KPI & Indicator & Explanation & Unit \\
\hline \multirow{3}{*}{ Supply } & \multirow{3}{*}{$\begin{array}{c}\text { Green } \\
\text { infrastructure } \\
\text { provision }\end{array}$} & $\begin{array}{c}\text { Number of trees, } \\
\text { grasslands, hedges, } \\
\text { flower/vegetation beds, } \\
\text { water surfaces } \\
\text { provided }\end{array}$ & & - & & & Thermal comfort & $\begin{array}{l}\text { Annual frequency of } \\
\text { thermal comfort for } \\
\text { the main functions }\end{array}$ & $\%$ and ${ }^{\circ} \mathrm{C}$ \\
\hline & & $\begin{array}{c}\text { Size of trees, grasslands, } \\
\text { hedges, } \\
\text { flower/vegetation beds, } \\
\text { water surfaces } \\
\text { provided }\end{array}$ & & $\mathrm{m}^{2}$ & \multirow{3}{*}{ Supply } & \multirow{3}{*}{$\begin{array}{l}\text { Green } \\
\text { infrastructure } \\
\text { provision }\end{array}$} & $\begin{array}{l}\text { Number of trees, } \\
\text { grasslands, hedges, } \\
\text { flower/vegetation beds, } \\
\text { water surfaces } \\
\text { provided }\end{array}$ & & - \\
\hline & & $\begin{array}{c}\text { Quality of trees, } \\
\text { grasslands, hedges, } \\
\text { flower/vegetation beds, } \\
\text { water surfaces } \\
\text { provided }\end{array}$ & & Qual & & & $\begin{array}{c}\text { Size of trees, grasslands, } \\
\text { hedges, } \\
\text { flower/vegetation beds, } \\
\text { water surfaces } \\
\text { provided }\end{array}$ & & $\mathrm{m}^{2}$ \\
\hline \multirow{3}{*}{ Consumption } & \multirow{3}{*}{ Energy } & $\begin{array}{l}\text { Fossil fuels } \\
\text { consumption }\end{array}$ & & $\mathrm{kg} / \mathrm{capita}$ & & & $\begin{array}{c}\text { Quality of trees, } \\
\text { grasslands, hedges, } \\
\text { flower/vegetation beds, } \\
\text { water surfaces } \\
\text { provided }\end{array}$ & & Qual \\
\hline & & $\begin{array}{l}\text { Ratio of passenger-km } \\
\text { travelled to } \\
\text { the respective energy } \\
\text { consumption }\end{array}$ & $\begin{array}{l}\text { To measure energy } \\
\text { efficiency }\end{array}$ & $\begin{array}{c}\mathrm{kg} / \text { passenger } \\
-\mathrm{km} \\
\text { travelled }\end{array}$ & \multirow[b]{2}{*}{ Consumption } & \multirow[b]{2}{*}{ Energy } & $\begin{array}{l}\text { Annual electrical } \\
\text { energy consumption } \\
\text { during operation }\end{array}$ & & $\mathrm{kWh} / \mathrm{m}^{2} \cdot \mathrm{y}$ \\
\hline & & $\begin{array}{c}\text { Renewable } \\
\text { and alternative fuels } \\
\text { usage }\end{array}$ & & $\%$ & & & $\begin{array}{l}\text { Percentage annual } \\
\text { electrical energy } \\
\text { demand fulfilled with } \\
\text { in-situ energy } \\
\text { production from } \\
\text { renewable energy } \\
\text { sources }\end{array}$ & & $\begin{array}{c}\% \\
\mathrm{kWh} / \mathrm{m}^{2} \cdot \mathrm{y}\end{array}$ \\
\hline
\end{tabular}


Table 4. Cont.

\begin{tabular}{|c|c|c|c|c|c|c|c|c|c|}
\hline \multicolumn{5}{|c|}{ Transport Infrastructure System } & \multicolumn{5}{|c|}{ Urban Space System } \\
\hline Theme & KPI & Indicator & Explanation & Unit & Theme & KPI & Indicator & Explanation & Unit \\
\hline \multirow{5}{*}{ Consumption } & \multirow[t]{2}{*}{ Water } & $\begin{array}{l}\text { Annual water } \\
\text { consumption during } \\
\text { operation for transport } \\
\text { infrastructure } \\
\text { maintenance }\end{array}$ & & $\mathrm{L} / \mathrm{m}^{2} \cdot \mathrm{y}$ & \multirow{5}{*}{ Consumption } & Energy & $\begin{array}{l}\text { Embedded energy in } \\
\text { construction materials }\end{array}$ & & $\mathrm{MJ} / \mathrm{kg}$ \\
\hline & & $\begin{array}{c}\text { Annual non-potable } \\
\text { water demand fulfilled } \\
\text { with in-situ depuration } \\
\text { and reuse }\end{array}$ & & $\% \mathrm{~L} / \mathrm{m}^{2} \cdot \mathrm{y}$ & & \multirow{3}{*}{ Water } & $\begin{array}{c}\text { Annual water } \\
\text { consumption during } \\
\text { operation for open } \\
\text { space maintenance }\end{array}$ & & $\mathrm{L} / \mathrm{m}^{2} \cdot \mathrm{y}$ \\
\hline & \multirow[t]{3}{*}{ Materials } & \multirow[t]{3}{*}{ Resource use } & & \multirow[t]{3}{*}{$\mathrm{kg} / \mathrm{m}^{2}$} & & & $\begin{array}{c}\text { Annual non-potable } \\
\text { water demand fulfilled } \\
\text { with in-situ depuration } \\
\text { and reuse }\end{array}$ & & $\% \mathrm{~L} / \mathrm{m}^{2} \cdot \mathrm{y}$ \\
\hline & & & & & & & $\begin{array}{c}\text { Public space } \\
\text { impervious area per } \\
\text { capita }\end{array}$ & $\begin{array}{l}\text { To measure water } \\
\text { run-off }\end{array}$ & $\mathrm{m}^{2} /$ capita \\
\hline & & & & & & Materials & $\begin{array}{l}\text { Local construction } \\
\text { materials } \\
\text { and components use }\end{array}$ & & $\mathrm{kg} / \mathrm{m}^{2}$ \\
\hline
\end{tabular}

Table 5. An indicator set for evaluating the transport and spaces systems-Part 4: The transportation and spaces systems impacts on social sectors (further details see the Supplementary Materials).

\begin{tabular}{|c|c|c|c|c|c|c|c|c|c|}
\hline \multicolumn{5}{|c|}{ Transport Infrastructure System } & \multicolumn{5}{|c|}{ Urban Space System } \\
\hline Theme & KPI & Indicator & Explanation & Unit & Theme & KPI & Indicator & Explanation & Unit \\
\hline \multirow{2}{*}{ Demography } & \multirow{2}{*}{$\begin{array}{l}\text { Socio-economic } \\
\text { characteristics }\end{array}$} & GDP per capita & & \$/capita & \multirow{2}{*}{ Demography } & \multirow{2}{*}{$\begin{array}{l}\text { Socio-economic } \\
\text { characteristics }\end{array}$} & GDP per capita & & \$/capita \\
\hline & & Employment rate & & $\%$ & & & Employment rate & & $\%$ \\
\hline \multirow{2}{*}{ Equity } & \multirow{2}{*}{ Social equity } & $\begin{array}{l}\text { Share of different } \\
\text { groups of people } \\
\text { exposed to air pollution }\end{array}$ & $\begin{array}{c}\text { To measure } \\
\text { the equity/justice of } \\
\text { exposure to air } \\
\text { pollution emissions }\end{array}$ & $\%$ & \multirow{2}{*}{ Equity } & \multirow{2}{*}{ Social equity } & $\begin{array}{l}\text { Share of different } \\
\text { groups of people } \\
\text { exposed to air pollution }\end{array}$ & $\begin{array}{c}\text { To measure } \\
\text { the equity/justice of } \\
\text { exposure to air } \\
\text { pollution emissions }\end{array}$ & $\%$ \\
\hline & & $\begin{array}{l}\text { Degree to which } \\
\text { vulnerable people's } \\
\text { needs are considered in } \\
\text { transport planning }\end{array}$ & & Qual & & & $\begin{array}{c}\text { Degree to which } \\
\text { vulnerable people's } \\
\text { needs are considered in } \\
\text { public space planning }\end{array}$ & & Qual \\
\hline
\end{tabular}


Table 5. Cont

\begin{tabular}{|c|c|c|c|c|c|c|c|c|c|}
\hline \multicolumn{5}{|c|}{ Transport Infrastructure System } & \multicolumn{5}{|c|}{ Urban Space System } \\
\hline Theme & KPI & Indicator & Explanation & Unit & Theme & KPI & Indicator & Explanation & Unit \\
\hline \multirow{3}{*}{ Inclusion } & $\begin{array}{c}\text { Public } \\
\text { participation }\end{array}$ & $\begin{array}{l}\text { Degree to which public } \\
\text { is involved in transport } \\
\text { planning process }\end{array}$ & & Qual & \multirow{3}{*}{ Inclusion } & $\begin{array}{c}\text { Public } \\
\text { participation }\end{array}$ & $\begin{array}{l}\text { Degree to which public } \\
\text { is involved in public } \\
\text { space design process }\end{array}$ & & Qual \\
\hline & \multirow{2}{*}{$\begin{array}{l}\text { Community } \\
\text { cohesion } \\
\text { and liveability }\end{array}$} & $\begin{array}{l}\text { Quality of interactions } \\
\text { among neighbours }\end{array}$ & & Qual & & \multirow{2}{*}{$\begin{array}{l}\text { Community } \\
\text { cohesion } \\
\text { and liveability }\end{array}$} & $\begin{array}{l}\text { Quality of interactions } \\
\text { among neighbours }\end{array}$ & & Qual \\
\hline & & $\begin{array}{c}\text { Community liveability } \\
\text { ratings }\end{array}$ & & Qual & & & $\begin{array}{c}\text { Community liveability } \\
\text { ratings }\end{array}$ & & Qual \\
\hline \multirow{5}{*}{ Health } & \multirow{4}{*}{$\begin{array}{l}\text { Physical } \\
\text { health }\end{array}$} & Population exposure & $\begin{array}{l}\text { Share of population } \\
\text { exposed to noise } \\
\text { and pollution levels } \\
\text { above the statutory } \\
\text { threshold }\end{array}$ & $\%$ & \multirow{4}{*}{ Health } & \multirow{3}{*}{$\begin{array}{l}\text { Physical } \\
\text { health }\end{array}$} & \multirow{3}{*}{ Physical health } & $\begin{array}{l}\text { Total time of doing } \\
\text { physical activity } \\
\text { within a day (or } \\
\text { a week) }\end{array}$ & h/d. capita \\
\hline & & Illness and mortality & $\begin{array}{l}\text { Number of chronic } \\
\text { respiratory illnesses, } \\
\text { respiratory } \\
\text { restricted activity } \\
\text { days and premature } \\
\text { deaths due to air } \\
\text { pollution }\end{array}$ & population & & & & $\begin{array}{l}\text { Average times of } \\
\text { doing physical } \\
\text { activity within } \\
\text { a day (or a week) }\end{array}$ & $\begin{array}{c}\text { times/d. } \\
\text { capita }\end{array}$ \\
\hline & & \multirow{2}{*}{ Physical activity } & $\begin{array}{c}\text { Portion of residents } \\
\text { who walk or bicycle } \\
\text { 15-min or more } \\
\text { daily }\end{array}$ & $\%$ & & & & $\begin{array}{c}\text { Duration of } \\
\text { medium or } \\
\text { vigorous physical } \\
\text { activity per day }\end{array}$ & h/d. capita \\
\hline & & & $\begin{array}{l}\text { Portion of children } \\
\text { walking or cycling } \\
\text { to school }\end{array}$ & $\%$ & & Mental health & Mental health benefits & & Qual \\
\hline & Mental health & Mental health benefits & & Qual & & Social & $\begin{array}{c}\text { The public's perceived } \\
\text { beauty }\end{array}$ & $\begin{array}{l}\text { By conducting } \\
\text { surveys }\end{array}$ & Qual \\
\hline Aesthetics & $\begin{array}{c}\text { Social } \\
\text { perception } \\
\text { and satisfaction }\end{array}$ & $\begin{array}{l}\text { Landscape visual } \\
\text { injures }\end{array}$ & & Qual & Aesthetics & $\begin{array}{l}\text { perception } \\
\text { and satisfaction }\end{array}$ & $\begin{array}{l}\text { Satisfaction of } \\
\text { the public spaces }\end{array}$ & $\begin{array}{l}\text { By conducting } \\
\text { surveys }\end{array}$ & Qual \\
\hline \multirow{4}{*}{ Affordability } & \multirow{3}{*}{$\begin{array}{l}\text { Transport } \\
\text { affordability }\end{array}$} & \multirow{3}{*}{$\begin{array}{l}\text { Share of household } \\
\text { budgets devoted to } \\
\text { transport }\end{array}$} & $\begin{array}{l}\text { Expenditures to } \\
\text { vehicles }\end{array}$ & $\$$ & \multirow{4}{*}{$\begin{array}{l}\text { Cultural } \\
\text { heritage }\end{array}$} & $\begin{array}{l}\text { Cultural } \\
\text { heritage } \\
\text { creation }\end{array}$ & Creating cultural trails & & Qual \\
\hline & & & $\begin{array}{l}\text { Expenditures to } \\
\text { parking }\end{array}$ & $\$$ & & \multirow{3}{*}{$\begin{array}{l}\text { Cultural } \\
\text { heritage } \\
\text { protection }\end{array}$} & $\begin{array}{c}\text { Protection } \\
\text { archaeological heritage }\end{array}$ & & Qual \\
\hline & & & $\begin{array}{l}\text { Expenditures to } \\
\text { transit services }\end{array}$ & $\$$ & & & $\begin{array}{c}\text { Protection UNESCO } \\
\text { sites }\end{array}$ & & Qual \\
\hline & $\begin{array}{l}\text { Affordable } \\
\text { housing }\end{array}$ & $\begin{array}{l}\text { Housing affordability } \\
\text { in accessible locations }\end{array}$ & & $\$$ & & & Protection viewpoints & & Qual \\
\hline
\end{tabular}


Table 5. Cont.

\begin{tabular}{|c|c|c|c|c|c|c|c|c|c|}
\hline \multicolumn{5}{|c|}{ Transport Infrastructure System } & \multicolumn{5}{|c|}{ Urban Space System } \\
\hline Theme & KPI & Indicator & Explanation & Unit & Theme & KPI & Indicator & Explanation & Unit \\
\hline & & & & & \multirow{4}{*}{$\begin{array}{l}\text { Cultural } \\
\text { heritage }\end{array}$} & \multirow{4}{*}{$\begin{array}{l}\text { Cultural } \\
\text { heritage } \\
\text { protection }\end{array}$} & $\begin{array}{l}\text { Protection places of } \\
\text { Taste }\end{array}$ & & Qual \\
\hline & & & & & & & $\begin{array}{l}\text { Protection places of } \\
\text { heterotopic }\end{array}$ & & Qual \\
\hline & & & & & & & $\begin{array}{l}\text { Protection places of } \\
\text { events }\end{array}$ & & Qual \\
\hline & & & & & & & $\begin{array}{l}\text { Protection places of } \\
\text { personality }\end{array}$ & & Qual \\
\hline
\end{tabular}

Table 6. An indicator set for evaluating the transport and spaces systems-Part 5: The transportation and spaces systems impacts on economic sectors (further details see the Supplementary Materials).

\begin{tabular}{|c|c|c|c|c|c|c|c|c|c|}
\hline \multicolumn{5}{|c|}{ Transport Infrastructure System } & \multicolumn{5}{|c|}{ Urban Space System } \\
\hline Theme & KPI & Indicator & Explanation & Unit & Theme & KPI & Indicator & Explanation & Unit \\
\hline \multirow{9}{*}{ Costs } & \multirow{3}{*}{ Investment } & $\begin{array}{c}\text { Public expenditures } \\
\text { and subsidies to transport } \\
\text { system }\end{array}$ & & $\$$ & \multirow{5}{*}{ Costs } & \multirow{2}{*}{ Investment } & $\begin{array}{c}\text { Public expenditures } \\
\text { and subsidies to transport } \\
\text { system }\end{array}$ & & $\$$ \\
\hline & & $\begin{array}{l}\text { Private capital to transport } \\
\text { system }\end{array}$ & & $\$$ & & & Intervention costs & & $\$$ \\
\hline & & Marginal costs of public funds & & $\$$ & & Land take & Land take cost & & $\$$ \\
\hline & Land take & Land take cost & & $\$$ & & $\begin{array}{l}\text { Planning and design } \\
\text { cost }\end{array}$ & $\begin{array}{c}\text { Investigation, planning, } \\
\text { designing cost in public } \\
\text { space design }\end{array}$ & & $\$$ \\
\hline & $\begin{array}{c}\text { Planning and design } \\
\text { cost }\end{array}$ & $\begin{array}{l}\text { Investigation, planning, } \\
\text { designing cost in transport } \\
\text { planning }\end{array}$ & & $\$$ & & $\begin{array}{c}\text { Operation } \\
\text { and maintenance }\end{array}$ & Maintenance costs and taxes & & $\$ / \mathrm{m}^{2}$ \\
\hline & $\begin{array}{c}\text { Operation } \\
\text { and maintenance }\end{array}$ & Fuel prices and taxes & & $\$$ & \multirow{4}{*}{ Benefits } & $\begin{array}{c}\text { Economy } \\
\text { and development }\end{array}$ & $\begin{array}{c}\text { Share of GDP contributed by } \\
\text { public spaces }\end{array}$ & & $\%$ \\
\hline & $\begin{array}{l}\text { Environment } \\
\text { compensation }\end{array}$ & $\begin{array}{l}\text { Compensation for ecological } \\
\text { effects and replacement of } \\
\text { environmental assets }\end{array}$ & & $\$$ & & Economic productivity & $\begin{array}{l}\text { Ratio of public spaces } \\
\text { revenues to the respective } \\
\text { maintenance } \\
\text { and operation cost }\end{array}$ & & $\%$ \\
\hline & \multirow[b]{2}{*}{ Traffic congestion } & Traffic congestion cost & & \$/capita & & \multirow[b]{2}{*}{ Property values } & Public amenity land values & & $\$$ \\
\hline & & $\begin{array}{c}\text { Average time spent traveling } \\
\text { under congested conditions per } \\
\text { year per capita } \\
\end{array}$ & & $\mathrm{h} / \mathrm{y} \cdot$ capita & & & Adjacent property values & & $\$$ \\
\hline
\end{tabular}


Table 6. Cont

\begin{tabular}{|c|c|c|c|c|c|c|c|c|c|}
\hline \multicolumn{5}{|c|}{ Transport Infrastructure System } & \multicolumn{5}{|c|}{ Urban Space System } \\
\hline Theme & KPI & Indicator & Explanation & Unit & Theme & KPI & Indicator & Explanation & Unit \\
\hline \multirow{4}{*}{ Benefits } & $\begin{array}{c}\text { Economy } \\
\text { and development }\end{array}$ & $\begin{array}{l}\text { Share of GDP contributed by } \\
\text { transport sector/share of GVA } \\
\text { generated by transport sector }\end{array}$ & & $\%$ & & & & & \\
\hline & Economic productivity & $\begin{array}{l}\text { Ratio of public transport } \\
\text { revenues to the respective } \\
\text { maintenance and operation cost }\end{array}$ & & $\%$ & & & & & \\
\hline & \multirow{2}{*}{ Property values } & Transport facility land values & & $\$$ & & & & & \\
\hline & & Adjacent property values & & $\$$ & & & & & \\
\hline
\end{tabular}




\section{Discussion}

This section takes these results and discusses the application of the indicator system in planning and research practices and the evaluation of the indicators. Our indicator set can be applied to a wide range of applications of transportation and spaces system integration. Primarily, it is necessary to investigate conflicts and to raise questions using fieldwork, survey, data analysis, and literature review, followed by an appraisal of the status quo systems through the prism of the indicator set. Afterwards, designers, practitioners, and other decision-makers could draft plans to solve the problems, engage with stakeholders, mediate conflicts, and transform the systems by providing a set of plan alternatives. Finally, the indicators can be used to assess the planned systems for supporting decision-makers to choose the best solution that is most likely to achieve the goals and objectives of a project while considering specific constraints. This approach leads to a transparent and repeatable evaluation, which is particularly relevant for sustainability assessment given the scale of the global challenge and the urgency to act, while also acknowledging the local situation, economic and social development, and limited resources that have to be used in a way to maximise impact.

In the presented indicator system, both qualitative and quantitative indicators are included. Though 57 KPIs identified in Table 7 could be measured quantitatively, some others are difficult to be assessed by quantitative methods, e.g., quality of transportation services, transport system management, public participation, equity, open space management, quality of adjacent transport infrastructure, the aesthetic quality of public spaces, cleanliness, and comfort. These factors, however, could be measured by the following qualitative approaches:

- Designers and planners' observations, analyses, and subjective judgments based on their professional knowledge; among others, assessments of aesthetic quality, cleanliness of public spaces, and the quality of related transportation infrastructure are suitable for using this method.

- Users' expression of their feelings and experiences in transport infrastructures and public spaces by conducting questionnaires, interviews, etc.; for example, appraisal of the quality of transportation services, public participation, equity, aesthetics, and the comfort of public spaces are appropriate for this technique.

- Collective knowledge generated from a multidisciplinary team of experts through brainstorming sessions, Delphi, expert consultation, and other methods that are beneficial for making comprehensive judgments on complex issues. In theory, the qualitative assessment of the aforementioned factors could all be achieved by this method, especially the appraisal of service and management quality. However, due to the fact that the Delphi method usually consumes a lot of time, labour, and financial resources, it is only used when necessary (or in large projects).

It is worth noting that there are two types of qualitative research: One is pure qualitative research with a lack of quantitative analysis, and the other is a higher level of qualitative evaluation that is based on quantitative analysis. In general, quantitative research can start from qualitative judgment and then use data analysis, statistics, simulation, and other techniques to generate more objective and precise judgments. Sometimes, however, results of quantitative studies could be opposite to the previous qualitative conclusions. Consequently, after making a quantitative judgment, it is necessary to describe the results qualitatively, such as summarising the rules and identifying impact factors. In quantitative evaluation, the reliability, consistency, and transparency of measurements in line with the time frames used are crucial issues.

Finally, it should be noted that while the selection of indicators presented here could be generally applicable within the proposed scope, the weighting of individual indicators will not be universal and was therefore not incorporated in this paper. It is key to establish weighting factors or priorities given a specific application, ideally through engagement by the problem owner with other stakeholders and based on local policies and circumstances following political, economic, business, and societal priorities. In the end the indicator system and its application have to support specific goals under given circumstances. The local context always drives the final selection and weighting of individual KPIs. 
In a future paper we will explore the role and application of these indicators in close collaboration with local stakeholders for the Jing-Zhang high-speed rail project in Beijing, which motivated this research, but the results presented here show that it is valuable to have an indicator system based on the literature in place before such discussions with any group of stakeholders.

Table 7. Quantifiable KPIs for transport and spaces systems evaluation (57 items).

\begin{tabular}{|c|c|c|c|c|}
\hline \multicolumn{3}{|c|}{ Hierarchy of the Goal System } & \multirow{2}{*}{\multicolumn{2}{|c|}{ Key Performance Indicators (KPIs) }} \\
\hline Level 1 & Level 2 & Level 3 & & \\
\hline $\begin{array}{l}\text { Transport system } \\
\text { performance considering } \\
\text { human behaviour }\end{array}$ & & & $\begin{array}{l}\text { (1) Intra-city rail transit: turnover, } \\
\text { infrastructure spatial features, } \\
\text { efficiency } \\
\text { (2) Inner-city rail transit: turnover, } \\
\text { infrastructure spatial features, } \\
\text { efficiency } \\
\text { (3) Road system: turnover, } \\
\text { infrastructure spatial features, public } \\
\text { transport infrastructure }\end{array}$ & $\begin{array}{l}\text { (4) Transport demand } \\
\text { (5) Modal split } \\
\text { (6) Mobility } \\
\text { (7) Safety: traffic accidents } \\
\text { and conflicts }\end{array}$ \\
\hline \multirow[t]{5}{*}{$\begin{array}{l}\text { Spaces system performance } \\
\text { considering human } \\
\text { behaviour }\end{array}$} & & & $\begin{array}{l}\text { (8) Furnishings } \\
\text { (9) Affiliated transport infrastructure } \\
\text { (10) Safety } \\
\text { (11) Use frequency }\end{array}$ & $\begin{array}{l}\text { (12) Use time } \\
\text { (13) Diversity } \\
\text { (14) Occupancy } \\
\text { (15) User diversity }\end{array}$ \\
\hline & $\begin{array}{l}\text { Transport-spaces } \\
\text { system } \\
\text { performance } \\
\text { considering human } \\
\text { behaviour }\end{array}$ & & $\begin{array}{l}\text { (16) Transport accessibility } \\
\text { (17) Transport connectivity } \\
\text { (18) Land-use accessibility } \\
\text { (19) Public space accessibility } \\
\text { (20) Spatial openness }\end{array}$ & $\begin{array}{l}\text { (21) Walkability } \\
\text { and bikeability } \\
\text { (22) Community severance } \\
\text { (23) Land use } \\
\text { (24) Parking }\end{array}$ \\
\hline & & $\begin{array}{l}\text { Transport-spaces } \\
\text { system } \\
\text { performance } \\
\text { considering natural } \\
\text { environment }\end{array}$ & $\begin{array}{l}\text { (25) Habitat integrity } \\
\text { (26) Biodiversity } \\
\text { (27) Air and water quality } \\
\text { (28) Waste recycling } \\
\text { (29) Noise and vibration impacts of } \\
\text { land transport projects } \\
\text { (30) Microclimate condition } \\
\text { (31) Bioclimatic comfort }\end{array}$ & $\begin{array}{l}\text { (32) Green infrastructure } \\
\text { provision } \\
\text { (33) Energy consumption } \\
\text { (34) Water consumption } \\
\text { (35) Materials consumption }\end{array}$ \\
\hline & & $\begin{array}{l}\text { Transport-spaces } \\
\text { system } \\
\text { performance } \\
\text { considering social } \\
\text { impacts }\end{array}$ & $\begin{array}{l}\text { (45) Socio-economic characteristics } \\
\text { (46) Physical health }\end{array}$ & $\begin{array}{l}\text { (47) Transport affordability } \\
\text { (48) Affordable housing }\end{array}$ \\
\hline & & $\begin{array}{l}\text { Transport-spaces } \\
\text { system } \\
\text { performance } \\
\text { considering } \\
\text { economic impacts }\end{array}$ & $\begin{array}{l}\text { (49) Investment } \\
\text { (50) Land take } \\
\text { (51) Planning and design cost } \\
\text { (52) Operation and maintenance } \\
\text { (53) Environment compensation }\end{array}$ & $\begin{array}{l}\text { (54) Traffic congestion } \\
\text { (55) Economy } \\
\text { and development } \\
\text { (56) Economic productivity } \\
\text { (57) Property values }\end{array}$ \\
\hline
\end{tabular}

\section{Conclusions}

Evaluation is a kind of value judgment behaviour that has a direct correlation with the goals and standards of projects. It includes the assessment of design goals, the baseline system, and the designed system. Initially, this article formulated a goal system and reviewed and synthesised the literature systematically to select themes and KPIs, all leading to the development of an indicator set that can be applied and support decision-making. The focus and main contribution of this paper is on the following themes: (1) integration of the transport system and the multi-level urban spaces system with an emphasis on microscale public spaces, (2) operational guidelines for generating and applying sustainability goals, and (3) to help track progress in achieving these goals by providing a systemic indicator set based on the goal system that can be applied to the interface of planning transport infrastructure, public spaces, and the impact of human behaviour in this context.

Regarding the goal system formulation, this study classified transportation and spaces system integration into three levels: internal integration, integration between subsystems, and integration between the system and the external environment. Under this hierarchy, three sets of goals and objectives are proposed for transport infrastructure redevelopment projects. On this basis, this study elicits themes and a longlist of indicators for transportation and spaces systems assessment based on a systematic literature review. According to the chosen selection criteria, $64 \mathrm{KPIs}$ are suitable for quantitative 
and qualitative analysis of the integration degree of a baseline system or planned system. This work also provides evaluation indicators and subitems for each KPI. Among these KPIs, qualitative and quantitative items are distinguished, and conventional qualitative assessment methods are outlined.

These indicators can support decision-makers in carefully evaluating their projects while considering the integration of multiple subsystems and can thus be part of public consultations as well as internal evaluation. Moreover, the proposed approach can be repeated in other sectors and used to select the relevant indicators from the literature systematically. A transparently designed and tailored indicator system can be used to inform the creation of evaluation tools, including simulation models, and provide a benchmark for consultation meetings. Finally, the use of the indicators post-construction is key to informing the design of surveys and implementing sensor systems to continue to monitor impact after a proposed plan has been turned into a physical intervention, from which further lessons can be shared and understood within the context of the selected indicators.

Supplementary Materials: The following are available online at http://www.mdpi.com/2071-1050/12/22/9677/s1, Table S1: Research scopes, scales, methods, number of themes, and indicators in key references (published before September 2020).

Author Contributions: Conceptualisation, L.Y.; methodology, L.Y.; formal analysis, L.Y.; investigation, L.Y.; writing-original draft preparation, L.Y. and K.H.v.D.; writing-review and editing, L.Y. and K.H.v.D.; proof reading, L.Y., K.H.v.D., and L.Z.; visualisation, L.Y.; supervision, L.Z. and K.H.v.D.; project administration, L.Z. All authors have read and agreed to the published version of the manuscript.

Funding: This research received no external funding.

Acknowledgments: The authors thank Fang Wang (Peking University), Wenyi Zhu (Tsinghua University), Nianxiong Liu (Tsinghua University), Tao Yang (China Academy of Urban Planning and Design), Fei Yan (Beijing Jiaotong University), and Zijia Wang (Beijing Jiaotong University) for giving insightful comments on the developed indicator set. We thank Baowei Li (Haidian Branch Bureau of Beijing Municipal Commission of Urban Planning) for providing information about the progress of the Jing-Zhang high-speed rail project. Finally, the authors would like to thank the anonymous reviewers for their thoughtful feedback and helpful comments on the manuscript.

Conflicts of Interest: The authors declare no conflict of interest.

\section{References}

1. United Nations. The Sustainable Development Goals Report 2020. Available online: https://unstats.un.org/ sdgs/report/2020/The-Sustainable-Development-Goals-Report-2020.pdf (accessed on 13 October 2020).

2. Chadwick, G. A Systems View of Planning: Towards a Theory of the Urban and Regional Planning Process; Pergamon Press: Oxford, UK, 1978.

3. Doron, G.M. The Dead Zone and the Architecture of Transgression. City 2000, 4, 247-263. [CrossRef]

4. Ravazzoli, E.; Torricelli, G.P. Urban mobility and public space. A challenge for the sustainable liveable city of the future. J. Public Space 2017, 2, 37-50. [CrossRef]

5. Cervero, R.; Guerra, E.; Al, S. Beyond Mobility: Planning Cities for People and Places; Island Press: Washington, DC, USA, 2017.

6. Yang, L.; Van Dam, K.H.; Majumdar, A.; Anvari, B.; Ochieng, W.Y.; Zhang, L. Integrated design of transport infrastructure and public spaces considering human behavior: A review of state-of-the-art methods and tools. Front. Arch. Res. 2019, 8, 429-453. [CrossRef]

7. Lopes, A.S.; Cavalcante, C.B.; Vale, D.S.; Loureiro, C.F.G. Convergence of planning practices towards LUT integration: Seeking evidences in a developing country. Land Use Policy 2020, 99, 104842. [CrossRef]

8. Bertolini, L. Integrating Mobility and Urban Development Agendas: A Manifesto. disP Plan. Rev. 2012, 48, 16-26. [CrossRef]

9. Kasraian, D.; Maat, K.; Stead, D.; Van Wee, B. Long-term impacts of transport infrastructure networks on land-use change: An international review of empirical studies. Transp. Rev. 2016, 36, 772-792. [CrossRef]

10. Ganning, J.; Miller, M.M. Transit oriented development and retail: Is variation in success explained by a gap between theory and practice? Transp. Res. Part D Transp. Environ. 2020, 85, 102357. [CrossRef]

11. Hauck, T.; Keller, R.; Kleinekort, V. Infrastructural Urbanism: Addressing the In-Between; DOM Publishers: Berlin, Germany, 2011. 
12. Yang, L.; Zhang, L.; Stettler, M.E.; Sukitpaneenit, M.; Xiao, D.; Van Dam, K.H. Supporting an integrated transportation infrastructure and public space design: A coupled simulation method for evaluating traffic pollution and microclimate. Sustain. Cities Soc. 2020, 52, 101796. [CrossRef]

13. Wegener, M. Overview of Land Use Transport Models. Handb. Transp. Model. 2004, 5, 127-146.

14. Moughtin, C. Urban. Design: Street and Square; Architectural Press: Oxford, UK, 2003.

15. Lévy, J. The City: Critical Essays in Human Geography; Routledge: New York, NY, USA, 2017.

16. Axelsson, R.; Ljung, M.; Blicharska, M.; Frisk, M.; Henningsson, M.; Mikusiński, G.; Folkeson, L.; Göransson, G.; Jönsson-Ekström, S.; Sjölund, A.; et al. The Challenge of Transdisciplinary Research: A Case Study of Learning by Evaluation for Sustainable Transport Infrastructures. Sustainability 2020, 12, 6995. [CrossRef]

17. Saidi, S.; Kattan, L.; Jayasinghe, P.; Hettiaratchi, P.; Taron, J. Integrated infrastructure systems-A review. Sustain. Cities Soc. 2018, 36, 1-11. [CrossRef]

18. Heeres, N.; Tillema, T.; Arts, J. Dealing with interrelatedness and fragmentation in road infrastructure planning: An analysis of integrated approaches throughout the planning process in the Netherlands. Plan. Theory Pract. 2016, 17, 421-443. [CrossRef]

19. Forester, J. Planning in the Face of Power; University of California Press: Berkeley, CA, USA, 1988; p. 123.

20. Oliveira, V.; Pinho, P. Evaluation in Urban Planning: Advances and Prospects. J. Plan. Lit. 2010, $24,343-361$. [CrossRef]

21. Faludi, A. A Decision-Centred View of Environmental Planning; Pergamon Press: Oxford, UK, 1987.

22. Carmona, M.; Tiesdell, S.; Heath, T.; Oc, T. Public Places, Urban Spaces: The Dimensions of Urban Design; Architectural Press: Oxford, UK, 2010.

23. Thompson, M.A. Determining impact significance in EIA: A review of 24 methodologies. J. Environ. Manag. 1990, 30, 235-250. [CrossRef]

24. Glasson, J.; Therivel, R.; Chadwick, A. Introduction to Environmental Impact Assessment: Principles and Procedures, Process, Practice and Prospects; UCL Press: London, UK, 1999.

25. United Nations. Indicators of Sustainable Development: Guidelines and Methodologies; United Nations: New York, NY, USA, 2007.

26. International Organization for Standardization 37120:2018. Sustainable Cities and Communities-Indicators for City Services and Quality of Life; ISO: Geneva, Switzerland, 2018.

27. Unit, E.I.; Siemens, A.G. (Eds.) European Green City Index: Assessing the Environmental Impact of Europe's Major Cities; Siemens A.G.: Munich, Germany, 2009.

28. Sadler, B. A framework for environmental sustainability assessment and assurance. In Handbook of Environmental Impact Assessment; Petts, J., Ed.; John Wiley \& Sons: Hoboken, NJ, USA, 1999; Volume 1, pp. 12-32.

29. Arcadis. Sustainable Cities Mobility Index 2017; Arcadis: Amsterdam, The Netherland, 2017.

30. Jeon, C.M.; Amekudzi, A. Addressing Sustainability in Transportation Systems: Definitions, Indicators, and Metrics. J. Infrastruct. Syst. 2005, 11,31-50. [CrossRef]

31. Badassa, B.B.; Sun, B.; Qiao, L. Sustainable Transport Infrastructure and Economic Returns: A Bibliometric and Visualization Analysis. Sustainability 2020, 12, 2033. [CrossRef]

32. Henke, I.; Cartenì, A.; Molitierno, C.; Errico, A. Decision-Making in the Transport Sector: A Sustainable Evaluation Method for Road Infrastructure. Sustainability 2020, 12, 764. [CrossRef]

33. Yu, X.; Ma, S.; Cheng, K.; Kyriakopoulos, G.L. An Evaluation System for Sustainable Urban Space Development Based in Green Urbanism Principles-A Case Study Based on the Qin-Ba Mountain Area in China. Sustainability 2020, 12, 5703. [CrossRef]

34. Moeckel, R.; Garcia, C.L.; Chou, A.T.M.; Okrah, M.B. Trends in integrated land-use/transport modeling. J. Trans. Land Use 2018, 11, 463-476.

35. Acheampong, R.A.; Silva, E. Land use-Transport interaction modeling: A review of the literature and future research directions. J. Transp. Land Use 2015, 8, 11-38. [CrossRef]

36. Yigitcanlar, T.; Dur, F. Developing a Sustainability Assessment Model: The Sustainable Infrastructure, Land-Use, Environment and Transport Model. Sustainability 2010, 2, 321-340. [CrossRef]

37. Zhao, P.; Chapman, R.; Randal, E.; Howden-Chapman, P. Understanding Resilient Urban Futures: A Systemic Modelling Approach. Sustainability 2013, 5, 3202-3223. [CrossRef] 
38. Wong, C. Developing quantitative indicators for urban and regional policy analysis. In Urban Policy Evaluation: Challenge and Change; Hambleton, R., Thomas, H., Eds.; Paul Chapman Publishing: Cardiff, UK, 1995; pp. 111-122.

39. Lombardi, P.; Giordano, S. Evaluating the Smart and Sustainable Built Environment in Urban Planning. In Handbook of Research on Social, Economic, and Environmental Sustainability in the Development of Smart Cities; Vesco, A., Ferrero, F., Eds.; IGI Global: Hershey, PA, USA, 2015; pp. 44-59.

40. Coombes, M.; Raybould, S.; Wong, C. Developing Indicators to Assess the Potential for Urban Regeneration; HM Stationery Office: Richmond, UK, 1992.

41. Garau, C.; Pavan, V.M. Evaluating Urban Quality: Indicators and Assessment Tools for Smart Sustainable Cities. Sustainability 2018, 10, 575. [CrossRef]

42. MacLaren, V.W. Urban Sustainability Reporting. J. Am. Plan. Assoc. 1996, 62, 184-202. [CrossRef]

43. Linstone, H.A.; Turoff, M. Introduction to the Delphi method: Techniques and applications. In The Delphi Method: Techniques and Applications; Addison-Wesley: Boston, MA, USA, 1975; pp. 3-12.

44. Nijkamp, P.; van Delft, A. Multi-Criteria Analysis and Regional Decision-Making; Springer Science \& Business Media: Leiden, The Netherlands, 1997; Volume 8.

45. Hill, M. A Goals-Achievement Matrix for Evaluating Alternative Plans. J. Am. Inst. Plan. 1968, 34, 19-29. [CrossRef]

46. Sdoukopoulos, A.; Pitsiava-Latinopoulou, M.; Basbas, S.; Papaioannou, P. Measuring progress towards transport sustainability through indicators: Analysis and metrics of the main indicator initiatives. Transp. Res. Part D Transp. Environ. 2019, 67, 316-333. [CrossRef]

47. Castillo, N.H.; Pitfield, D.E. ELASTIC-A methodological framework for identifying and selecting sustainable transport indicators. Transp. Res. Part D Transp. Environ. 2010, 15, 179-188. [CrossRef]

48. Lim, S.; Pettit, S.; Abouarghoub, W.; Beresford, A. Port sustainability and performance: A systematic literature review. Transp. Res. Part D Transp. Environ. 2019, 72, 47-64. [CrossRef]

49. Visser, M.; van Eck, N.J.; Waltman, L. Large-scale comparison of bibliographic data sources: Scopus, Web of Science, Dimensions, Crossref, and Microsoft Academic. arXiv 2020, arXiv:2005.10732. Available online: https://arxiv.org/abs/2005.10732 (accessed on 18 November 2020).

50. Chen, C. CiteSpace II: Detecting and visualising emerging trends and transient patterns in scientific literature. J. Am. Soc. Inf. Sci. Technol. 2006, 57, 359-377. [CrossRef]

51. Bryman, A. Social Research Methods; Oxford University Press: Oxford, UK, 2016.

52. Cervero, R. Transport Infrastructure and Global Competitiveness: Balancing Mobility and Livability. Ann. Am. Acad. Polit. Soc. Sci. 2009, 626, 210-225. [CrossRef]

53. Fewings, P.; Henjewele, C. Construction Project Management: An. Integrated Approach; Routledge: Abingdon, UK, 2019.

54. American Institute of Architects. Livability 101: What Makes A Community Livable? American Institute of Architects: Washington, DC, USA, 2005.

55. Pollalis, S.N. Planning Sustainable Cities: An Infrastructure-Based Approach; Routledge: Abingdon, UK, 2016.

56. Ritchie, A.; Thomas, R. Sustainable Urban Design: An Environmental Approach; Taylor \& Francis: Abingdon, UK, 2013.

57. Kirchherr, J.; Reike, D.; Hekkert, M. Conceptualising the circular economy: An analysis of 114 definitions. Resour. Conserv. Recycl. 2017, 127, 221-232. [CrossRef]

58. Freeman, L.C. Centrality in social networks: Conceptual clarification. Soc. Netw. 1979, 1, 215-239. [CrossRef]

Publisher's Note: MDPI stays neutral with regard to jurisdictional claims in published maps and institutional affiliations.

(C) 2020 by the authors. Licensee MDPI, Basel, Switzerland. This article is an open access article distributed under the terms and conditions of the Creative Commons Attribution (CC BY) license (http://creativecommons.org/licenses/by/4.0/). 